\title{
The early Pliocene Titiokura Formation: stratigraphy of a thick, mixed carbonate-siliciclastic shelf succession in Hawke's Bay Basin, New Zealand
}

\author{
KYLE J. BLAND \\ PETER J. J. KAMP \\ ARNE PALLENTIN \\ RHYS GRAAFHUIS \\ CAMPBELL S. NELSON \\ VINCENT CARON \\ Department of Earth Sciences \\ The University of Waikato \\ Private Bag 3105 \\ Hamilton 2001, New Zealand
}

\begin{abstract}
This paper presents a systematic stratigraphic description of the architecture of the early Pliocene Titiokura Formation (emended) in the Te Waka and Maungaharuru Ranges of western Hawke's Bay, and presents a facies, sequence stratigraphic, and paleoenvironmental analysis of the sedimentary succession. The Titiokura Formation is of early Pliocene (Opoitian-Waipipian) age, and unconformably overlies Mokonui Formation, which is a regressive late Miocene and early Pliocene (Kapitean to early Opoitian) succession. In the Te Waka Range and the southern parts of the Maungaharuru Range, the Titiokura Formation comprises a single limestone sheet $20-50 \mathrm{~m}$ thick, with calcareous sandstone parts. In the vicinity of Taraponui Trig, and to the northeast, the results of 1:50000 mapping show that the limestone gradually partitions into five members, which thicken markedly to the northeast to total thicknesses of $\mathrm{c}$. $730 \mathrm{~m}$, and concomitantly become dominated by siliciclastic sandstone. The members (all new) from lower to upper are: Naumai Member, Te Rangi Member, Taraponui Member, Bellbird Bush Member, and Opouahi Member. The lower four members are inferred to each comprise an obliquitycontrolled $41000 \mathrm{yr}$ 6th order sequence, and the Opouahi Member at least two such sequences. The sequences typically have the following architectural elements from bottom to top: disconformable sequence boundary that formed as a transgressive surface of erosion; thin transgressive systems tracts (TSTs) with onlap and backlap shellbeds, or alternatively, a single compound shellbed; downlap surface; and very thick $(70-200 \mathrm{~m})$ highstand (HST) and regressive systems tracts (RST) composed of fine sandstone. The sequences in the Opouahi Member have cryptic TSTs, sandy siltstone to silty sandstone HSTs, and cross-bedded, differentially cemented, fine sandstone RSTs; a separate variant is an $11 \mathrm{~m}$ thick bioclastic limestone (grainstone and packstone) at the top of the member that crops out in the
\end{abstract}

G03062; Online publication date 1 December 2004 Received 25 August 2003; accepted 19 May 2004 vicinity of Lake Opouahi. Lithostratigraphic correlations along the crest of the ranges suggest that the Titiokura Formation, and its correlatives to the south around Puketitiri, represent a shoreline-to-shelf linked depositional system. Carbonate production was focused around a rocky seascape as the system onlapped basement in the south, with dispersal and deposition of the comminuted carbonate on an inner shelf to the north, which was devoid of siliciclastic sediment input. The rates of both subsidence and siliciclastic sediment flux increased rapidly to the northeast of the carbonate "platform", with active progradation and offlap of the depositional system into more axial parts of Hawke's Bay Basin.

Keywords Pliocene; Opoitian; Waipipian; Hawke's Bay Basin; Te Aute limestone lithofacies; sequence stratigraphy; Titiokura Formation; Naumai Member; Te Rangi Member; Taraponui Member; Bellbird Bush Member; Opouahi Member; new stratigraphic names

\section{INTRODUCTION}

The Titiokura Formation is a mixed carbonate-siliciclastic succession of early Pliocene age forming prominent bluffs and dip-slopes in the Te Waka and Maungaharuru Ranges along the western margin of Hawke's Bay Basin (Fig. 1). This formation is part of the Te Aute lithofacies limestone of Beu (1995), which is a descriptive term for the numerous Pliocene barnacle-dominated yellow-coloured limestone units of eastern North Island. In the synthesis volume of the Pliocene limestones and their scallops, Beu (1995) restricted the Titiokura Limestone to a unit of Waipipian age exposed along the northwestern side of the Te Waka Range south of State Highway 5 (SH5; Napier-Taupo Road) (Fig. 1). The much thicker succession of interbedded limestone and sandstone forming the crest of the Maungaharuru Range north of SH5 was referred to the Maungaharuru Formation (Cutten 1994), and on balance attributed an Opoitian age, although a Waipipian age could not be ruled out for the upper part of the formation (Beu 1995). Subsequent regional mapping by Francis (1991), Graafhuis (2001), and Bland (2001) suggests that the Titiokura Limestone and the limestone-bearing parts of the Maungaharuru Formation are probably part of the same depositional system; consequently, understandings about the origin of these units can usefully be advanced by associating them stratigraphically. As this and related work (K. Bland, $\mathrm{PhD}$ thesis in prep. "Analysis of the Late Miocene-Early Pleistocene Hawke's Bay Basin”) shows, the limestonebearing succession is cyclothemic, onlaps to the south in the Te Waka Range, and, in parts of the Maungaharuru Range, has been disrupted by large scale slumping. We infer that the Titiokura Limestone mapped and described by Beu (1995) is an upper sequence(s) within a stack of sequences that are thicker and mostly older in the more northerly sited Maungaharuru Range. 


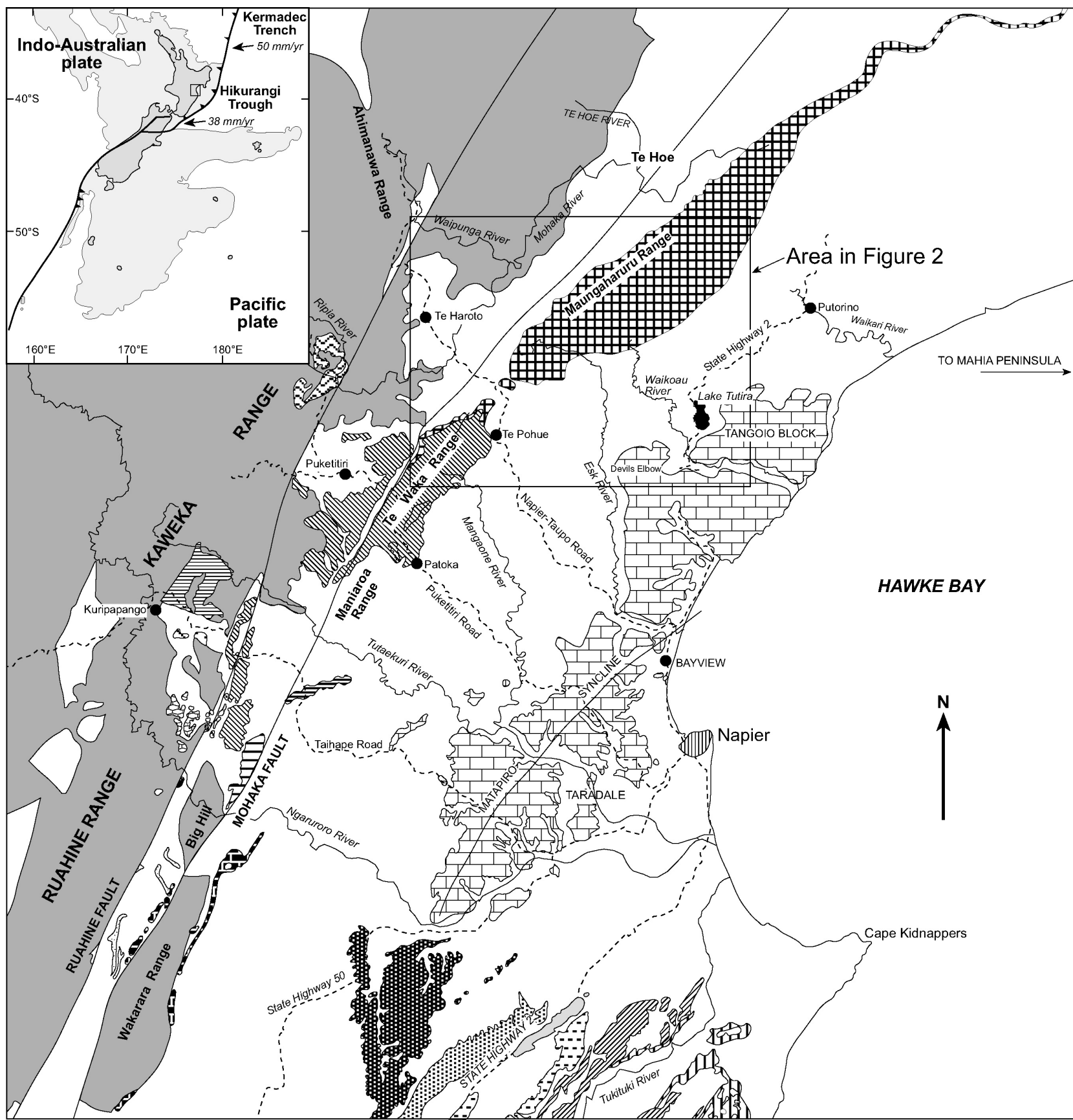

\section{Western margin}

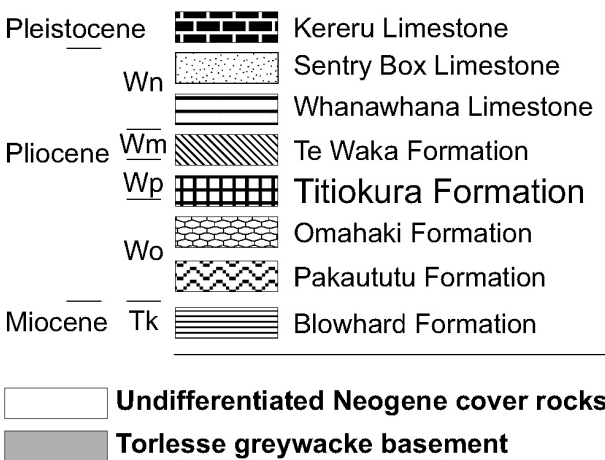

\section{Eastern margin}

Pleistocene

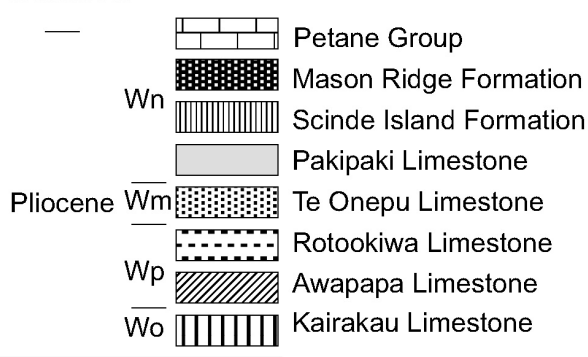
15 15 30

Fig. 1 Generalised distribution of Pliocene-Pleistocene limestone formations in Hawke's Bay Basin (after Beu (1995), with modifications from Bland (2001, in prep.), Graafhuis (2001), and Caron (2002)). New Zealand biostratigraphic stage abbreviations: Tk, Kapitean; Wo, Opoitian; Wp, Waipipian; Wm, Mangapanian; Wn, Nukumaruan. Note the nomenclature for stratigraphic units that crop out along the western versus eastern margins of the basin. Inset: The tectonic setting of the New Zealand region. 


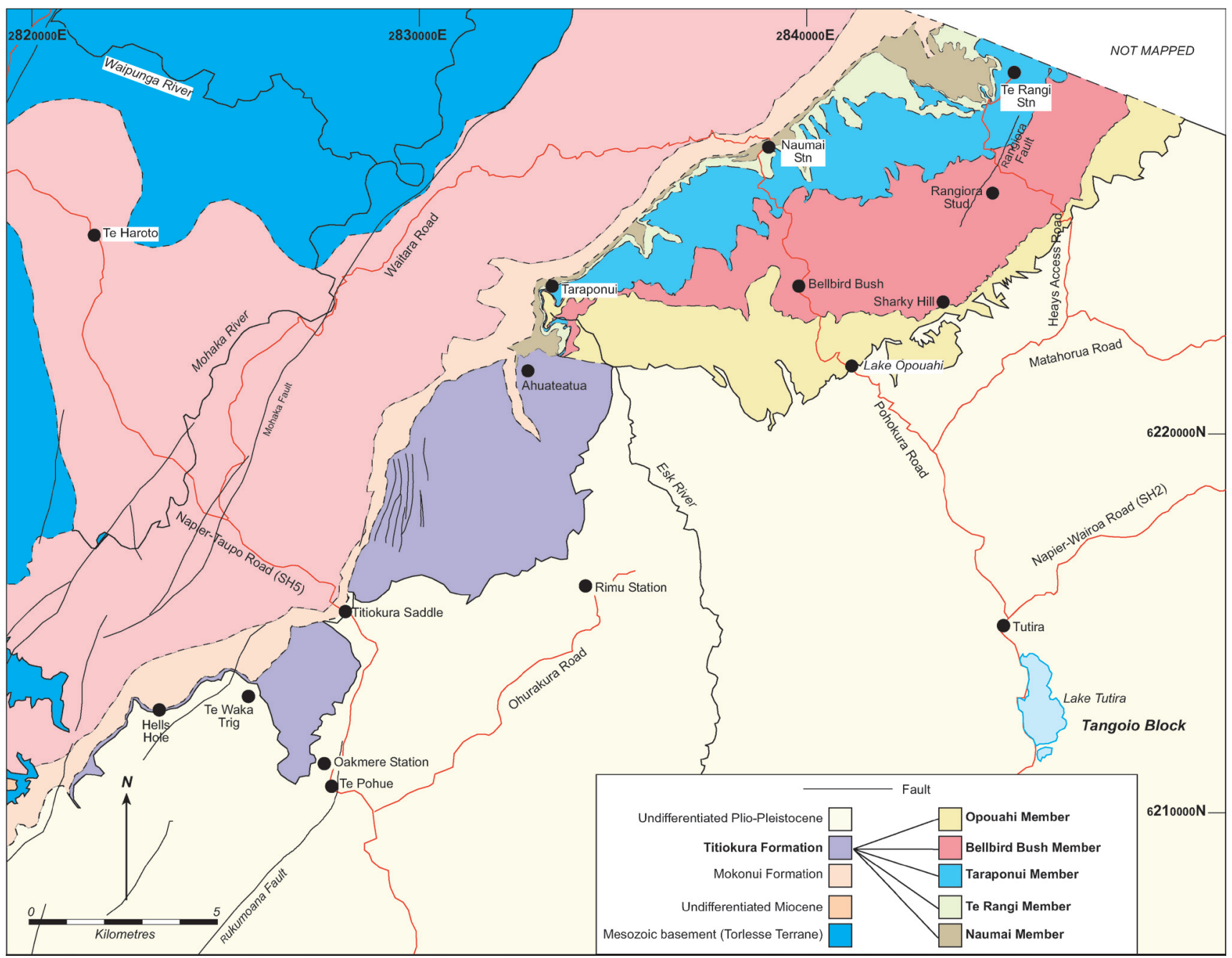

Fig. 2 Simplified geological map of part of western Hawke's Bay (outlined in Fig. 1), highlighting the distribution of the Titiokura Formation and its differentiation into five members. Map has been adapted from Grindley (1960), Bland (2001), and Graafhuis (2001), with modifications from Bland (in prep.).

This paper provides new information on the stratigraphy, facies, sequence stratigraphy, and depositional paleoenvironments of the Titiokura Formation. The formation marks an important change in the character and evolution of the central Hawke's Bay part of the basin, as these and younger sediments, despite their considerable thicknesses, accumulated in diversified shelf environments, compared with the underlying (Tongaporutuan) bathyal mudstone and regressive Mokonui Formation (Cutten 1994). The move to more detailed investigation of the internal characteristics of the Te Aute lithofacies, supported by mapping, is a natural follow-on from the comprehensive synthesis of the occurrence, biostratigraphy, and distribution of these lithofacies completed by Beu et al. (1980) and Beu (1995). The results of the work reported here on the Titiokura Formation on the northwestern margin of the basin complement detailed work on the Te Aute lithofacies on the southeastern margin of the basin (Caron 2002; Caron \& Nelson 2003; Caron et al. 2004, this issue).

\section{GEOLOGICAL SETTING}

Titiokura Formation (Titiokura Limestone of Beu (1995) and the lower part of the Maungaharuru Formation of Cutten (1994)) occurs about midway within a $5-7 \mathrm{~km}$ thick late Miocene to late Pliocene succession dominated by siliciclastic sediments, representing the Tongaporutuan-Nukumaruan development and infilling of Hawke's Bay Basin (Fig. 2). The deposits underlying the Titiokura Formation chiefly involve Tongaporutuan-Kapitean Waitere Formation (Cutten 1994), which ranges from c. 1 to $4 \mathrm{~km}$ thick along the western side of the Maungaharuru Range. The Waitere Formation has a lower transgressive shelf sandstone member (Te Ipuohape Sandstone Member, lower Tongaporutuan) up to several hundred metres thick that onlaps older Neogene units and oversteps on to basement in a southwestward direction along the axial range. It is overlain by a very thick ( $850-3000 \mathrm{~m})$ bathyal mudstone (Rakaita Siltstone Member) that thickens to the northeast and reflects late Miocene rapid and substantial basin subsidence. 

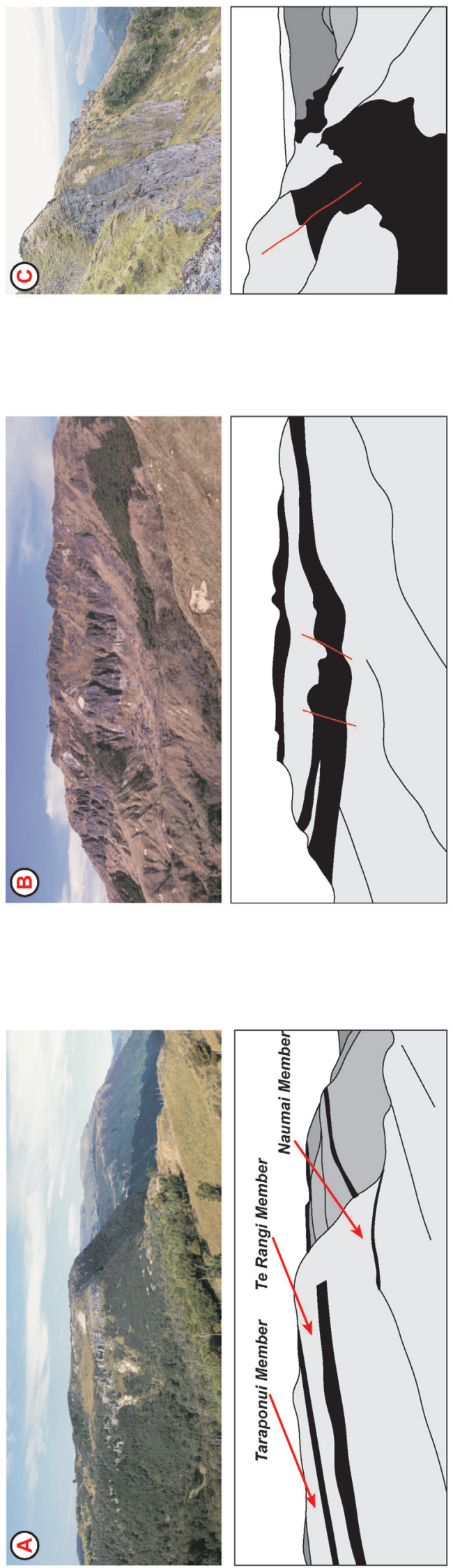
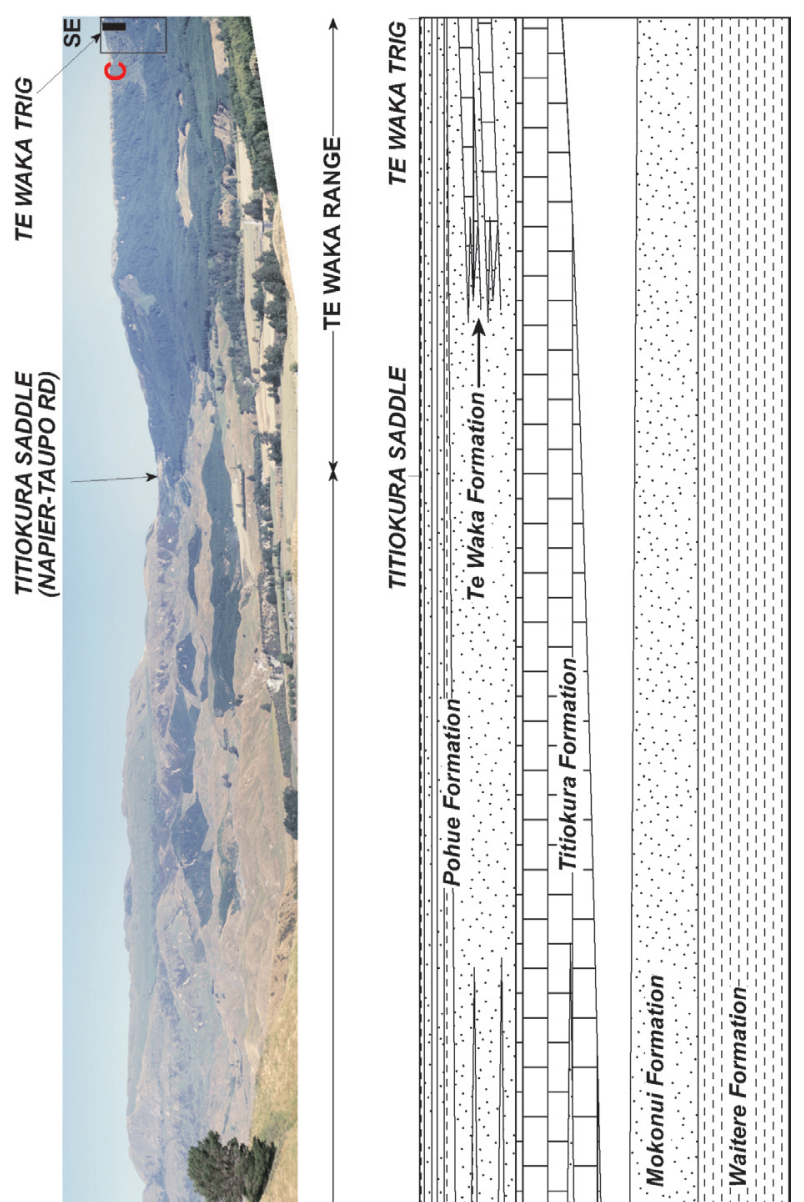

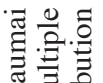

:

a.

言.

의

$>$ 吾車

4 我

s.

․․ㄹ

要

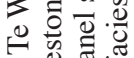

․․․

을

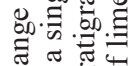

$\approx$ 운

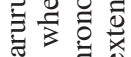

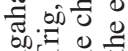

政

$\sum$ 诺

政寻

寻安泀的

흘

更 0

오를 윰

풍

응 응

青

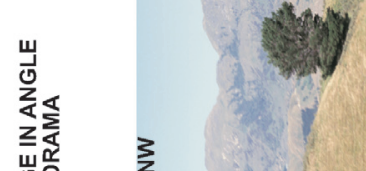

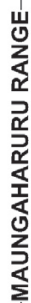

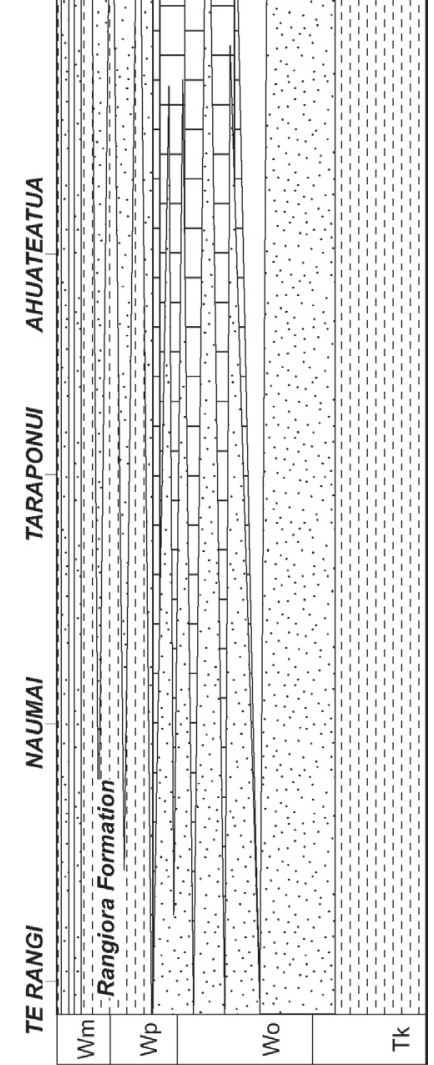

过

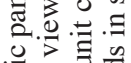

을

를.일 음

.0.0.

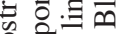

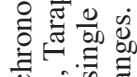

ปी 0 क ज्ञ

过

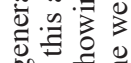

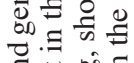

ज. $.00 . \Xi$

की

잉

훈

\&

s.

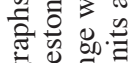

列

물

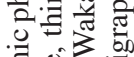

矛运焉

ह

भ. 
The Rakaita Siltstone Member is unconformably overlain by the early Kapitean to early Opoitian Mokonui Formation (Cutten 1994) in a cutting on SH5, but elsewhere to the north along most of the Maungaharuru Range this contact is gradational. Facies analysis indicates that the upper part of the Mokonui Formation accumulated in inner shelf to shoreface paleoenvironments. The Mokonui Formation is unconformably overlain by the Titiokura Formation. This contact may mark a substantial change in the paleogeographic development of the basin, as it is the point at which carbonate beds become an obvious stratigraphic component (Te Aute lithofacies) of the basin succession, the overlying stratigraphy becomes lithologically very diversified, the basin depocentre shifts southeastward towards the axis of the Matapiro Syncline, and the inboard margin of the accretionary prism in the coastal hill country of southern Hawke's Bay starts to emerge above sea level (Beu et al. 1980, Kamp 1982; Pettinga 1982; Beu 1995).

The marked erosion of the Waitere Formation in the modern landscape, reflected in the formation of the Mokaha River valley, has removed any stratigraphic continuity that may have formerly existed between the Titiokura Formation in the Maungaharuru Range (Fig. 3) and the Torlesse greywacke basement in the axial range to the west (Fig. 1,2). Hence, the relationship of the Titiokura Formation to basement cannot be established immediately west of the Maungaharuru Range. This can, however, be established through mapping of Pliocene units to the south. Opoitian limestone outliers have recently been mapped between the Kaweka and Ruahine Faults just north of Puketitiri, and west of the Mohaka Fault, in the vicinity of the Ripia River (Bland et al. 2003) (Fig. 1). This limestone unit is named Pakaututu Formation (Fig. 1) and it is characterised by abundant robust bivalves, especially Tucetona laticostata and common Phialopecten marwicki, and abundant greywacke breccia and conglomerate at its base, which has marked relief suggestive of a rocky paleocoastline with sea stacks. The most continuous outcrop and contact with basement can be observed above and southeast of the Ripia River (e.g., NZMS 260 metric grid reference V19/128209-V20/134195), where the limestone is overlain by sandy siltstone with up to $50 \mathrm{~m}$ of section preserved. East of the Ruahine Fault, a lithologically similar limestone containing Phialopecten marwicki is considered to be a correlative unit. The contact with basement is located near the bottom of valleys (e.g., V20/120117), but is not obviously exposed, although the basement contact can be shown to be c. $50 \mathrm{~m}$ lower in elevation, being overlain by a marine sandstone and conglomerate, which reach their greatest thickness (50 m) adjacent to the Ruahine Fault. The Pakaututu Formation in this area is overlain by $120 \mathrm{~m}$ of poorly exposed siltstone, which coarsens upward to sandy siltstone, in turn unconformably overlain by the Te Waka Formation. Another calcareous formation of probable Opoitian age (Beu 1995), known as the Omahaki Formation, has been described from the Omahaki Depression (Kingma 1957) west of Ruahine Fault and well to the south of Puketitiri (Fig. 1). This unit is 5-20 m thick and comprises a carbonate cemented, sparsely fossiliferous conglomerate with sandstone interbeds that accumulated over greywacke basement (Beu 1995). Caron (2002) reported a $20 \mathrm{~m}$ thick calcareous sandstone with large scale trough cross-beds at the southern end of the Glenross Range (U21/032867), which is probably part of the Omahaki Formation. The Omahaki Formation accumulated through marine onlap over an indurated rocky surface.
The Opoitian age of the Pakaututu Formation and Omahaki Formation implies that they are correlatives of the lower part of the Titiokura Formation in the Maungaharuru Range, but slightly older than Beu's (1995) Titiokura Limestone at Te Waka Trig. These differences in the stratigraphy along the range front can be attributed to differences in early Pliocene paleogeography. The Pakaututu Formation and Omahaki Formation accumulated on basement as transgressive onlap facies, while the Titiokura Formation formed as part of a linked depositional system farther north in the basin involving the dispersion of sediments on a subsiding shelf, the carbonate sediment having been sourced from the contemporary carbonate factories at or near the more southern rocky shorelines, and being transported offshore to the north by strong tidal currents. There is no direct evidence that the Titiokura Formation onlapped basement immediately west of the Maungaharuru Range. The strike-slip fault zones between the Pakaututu Formation and Titiokura Formation probably formed during the Nukumaruan (Erdman \& Kelsey 1992; Bland et al. 2003), and associated uplift and erosion have removed the original stratigraphic continuity between them. Consequently, we refer to the Titiokura Formation as an example of a continent-attached mixed carbonate-siliciclastic depositional system. It provides a new perspective on the Te Aute lithofacies because it reveals a highly oblique section from a shoreline across the early Pliocene paleo-shelf, enabling some insights to be gained into the cross-shelf profile of these lithofacies. This contrasts with similar aged Te Aute lithofacies units exposed along the southeastern margin of the inland seaway, such as the Opoitian Kairakau Limestone and Waipipian Awapapa Limestone, which show limited down-dip exposure (Kamp et al. 1988; Caron 2002).

The Maungaharuru Formation as defined by Cutten (1994) is a very thick and lithologically diverse unit, which includes beds ranging in age from Opoitian to early Nukumaruan. Mapping by Bland (2001, in prep.) and Graafhuis (2001) has subdivided this unit into numerous formations and members. In their stratigraphic rationalisation, the name Maungaharuru Formation has been abandoned, and we adopt the name Titiokura Formation for the Opoitian-Waipipian limestone-bearing succession in the Maungaharuru Range and the Te Waka Range, thereby expanding the usage of Titiokura Limestone of Beu (1995), but changing the name to substitute the term "Formation" for "Limestone" in recognition of the siliciclastic content of correlative beds in the Maungaharuru Range.

\section{STRATIGRAPHY}

\section{TITIOKURA FORMATION (emended)}

NAME AND DEFINITION: The Titiokura Limestone was formally defined by Beu (1995) for a 50 m thick Waipipian limestone at Titiokura Summit in the Te Waka Range near Te Pohue, immediately south of SH5 (Napier-Taupo Road), where it underlies brown sandstone traditionally included in the Te Waka Formation (Fig. 4). Here, we formally emend the name Titiokura Limestone (Beu 1995) to Titiokura Formation, to accommodate the lithological variation evident in the beds in the Manugaharuru Range that we now include in the one depositional system, which ranges in age from Opoitian to Waipipian. 

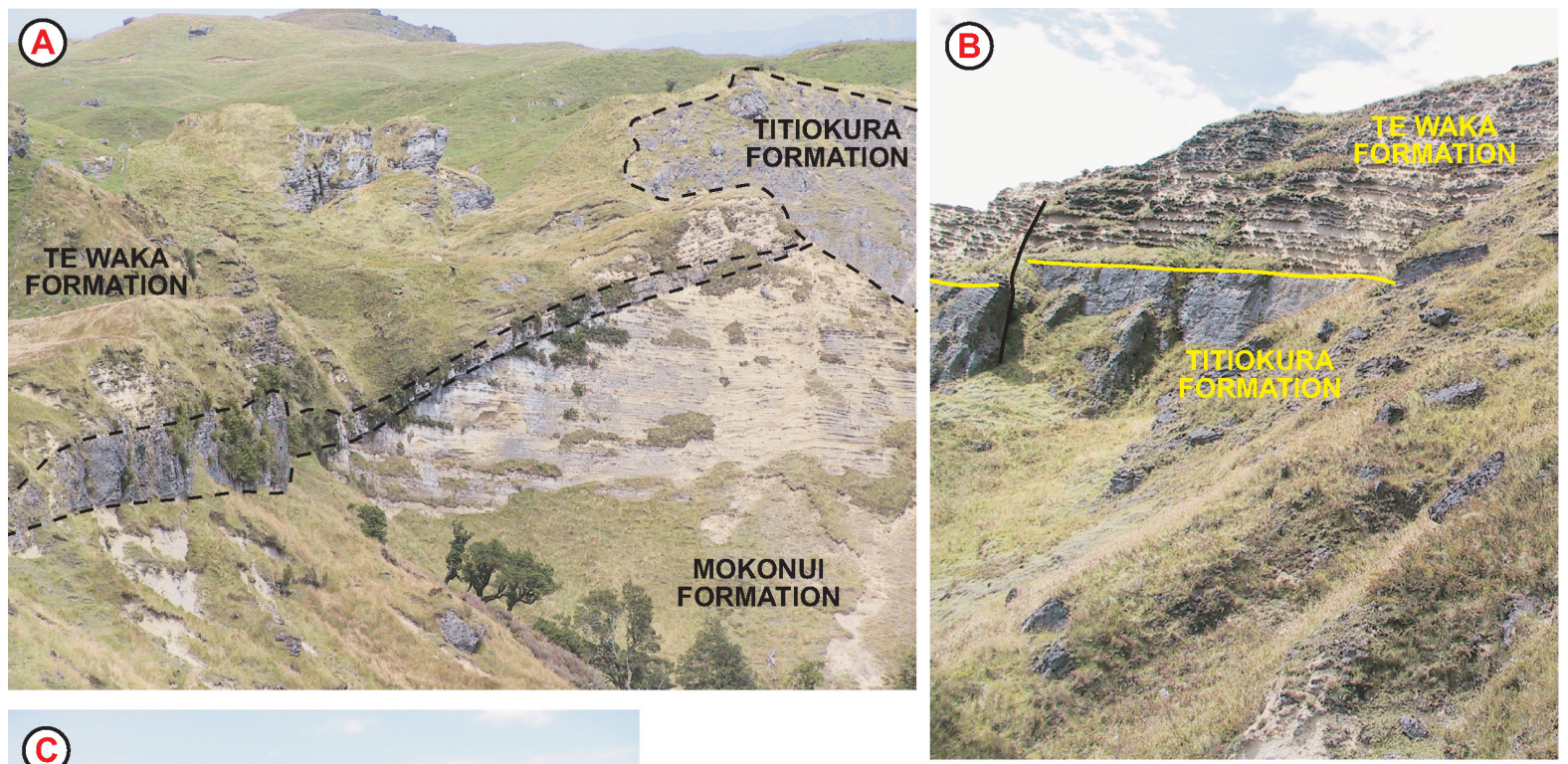

(C)
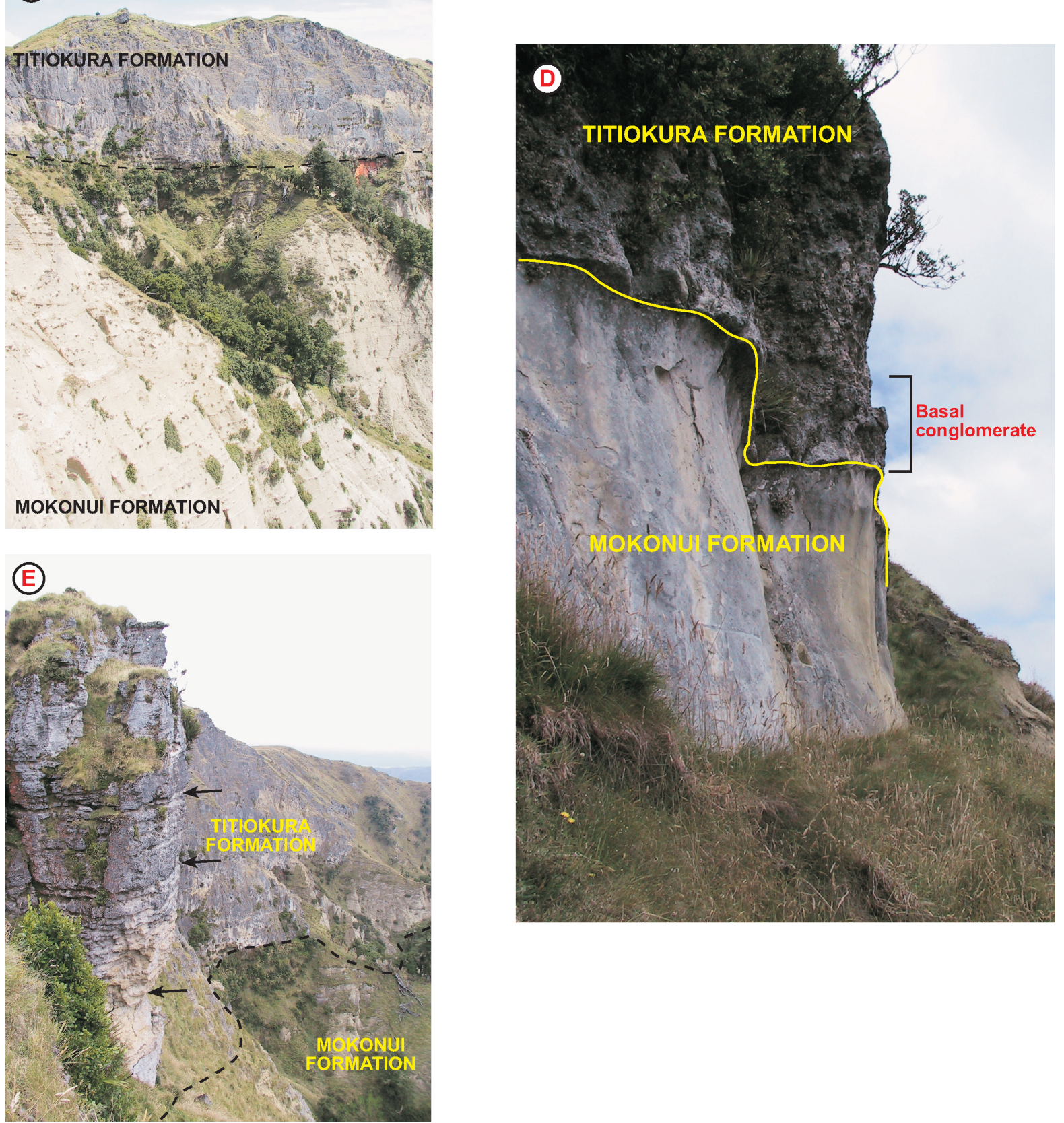
We retain the name "Titiokura" in Titiokura Formation for several reasons. In Beu et al. (1980) the Titiokura Limestone was mapped along the eastern side of Maungaharuru Range, where it was applied to a clear limestone facies considered at the time to be Waipipian in age. Subsequently, Beu (1995) raised uncertainty about the Waipipian age of northern occurrences of this limestone unit near Lake Opouahi (V19/ 403227; Fig. 2), and chose to restrict Titiokura Limestone sensu stricto to the Te Waka Range. All of the limestone units in the Maungaharuru Range were then included by Beu (1995) in the Maungaharuru Formation, a unit that had been redefined by Cutten (1994) to include all strata above the Mokonui Formation through to the Mangapanian conglomerate units on Matahorua Road near Lake Tutira (Fig. 2). Mapping by Graafhuis (2001) showed that the Maungaharuru Formation within Cutten's map area, and farther to the east, can very usefully be subdivided into multiple units, some of them being discrete sequences. As the new map units will require new names, we will raise the Maungaharuru Formation to subgroup rank (e.g., Bland in prep.). This leaves open the need for a name for the limestone and associated lithofacies of Opoitian-Waipipian age in the Maungaharuru and Te Waka Ranges, for which we apply the name Titiokura Formation.

A previously unknown limestone at the base of a section in Wai-iti Stream near Patoka (Gorges Section, V20/188007) was interpreted by Caron (2002) to be Titiokura Formation, thereby extending its known occurrence significantly to the south of Te Pohue (Fig. 1).

TYPE AND REFERENCE SECTIONS: Beu (1995) established a type locality (V20/278148) for the Titiokura Formation at the northern end of Te Waka Range. The base of the formation is not well exposed at that locality, and therefore we establish a new type section for the formation $3 \mathrm{~km}$ along the ridge crest to the south at V20/248133, where there is complete exposure of the formation from bottom to top (Fig. 4A, 5). Good accessible exposures of the formation occur along SH5 at V20/289142-287144. A good reference section along the down-dip eastern side of the Te Waka Range is located on Oakmere Station above Te Pohue village (Caron 2002, column 38, V20/275115). Another useful reference section characterising the stratigraphy of Titiokura Formation in the central part of the Maungaharuru Range occurs on the western side of Taraponui Trig (V19/331228) (Fig. 5). A reference section in the northern part of the Maungaharuru Range (V19/387273-408218) is located along Pohokura Road, east of the intersection with Jeph Everett Road to Lake Opouahi.
DISTRIBUTION AND BOUNDARIES: The distribution of the Titiokura Formation within the Maungaharuru and Te Waka Ranges has been mapped at 1:50 000 (Bland 2001, in prep.; Graafhuis 2001). The generalised distribution is illustrated in Fig. 2. The Titiokura Formation occurs exclusively east of Mohaka Fault, and everywhere overlies the Mokonui Formation (Fig. 3). It has an erosional contact with Mokonui Formation for c. $30 \mathrm{~km}$ along the western face of the Te Waka (Fig. 4) and Maungaharuru Ranges, but this contact becomes conformable in the northernmost parts of Maungaharuru Range, where the paleogeography allowed for continuous sedimentation.

The upper contact of the Titiokura Formation south and west of SH5 has been mapped around a prominent dip-slope and along the western face of Te Waka Range (Fig. 2). Beu (1995) suggested that the contact in this area is unconformable, but our observations are that the upper contact is sharp but conformable at Oakmere Station near Te Pohue, or gradational and conformable along the western face of the Te Waka Range (Fig. 4A,B). In the Maungaharuru Range, the upper contact of the Titiokura Formation occurs in catchments facing east off the range. Invariably, the mapped position of this contact is inferred, as good exposures have not been located due to the occurrence of extensive slump deposits. The contact is inferred to be conformable and overlain by siliciclastic siltstone and sandstone of the Rangiora Formation (Fig. 3) (Graafhuis 2001).

THICKNESS: The Titiokura Formation varies from a few metres thick to composited thicknesses of c. $730 \mathrm{~m}$ (Fig. 5, 6). These measurements have been made along the northeast-southwest-trending western faces of the Te Waka and Maungaharuru Ranges; it is expected that correlative beds will increase in thickness eastward into subsurface parts of Hawke's Bay Basin. This is suggested by a systematic decrease in dip upwards within the members of the Titiokura Formation in the vicinity of Naumai and Te Rangi Stations, such that beds will diverge and thicken southeastward into the basin. An outlier of Titiokura Formation at Patoka has a thickness of $20 \mathrm{~m}$, but this is likely to be only the uppermost part of the formation. Along the western face of the Te Waka Range, Titiokura Formation overlies and infills a spectacular paleo-relief carved into underlying Mokonui Formation (Fig. 4). Relief on this surface may locally be as much as 20 $30 \mathrm{~m}$. As a result, the Titiokura Formation shows prominent local thickness changes ranging from 2 to $75 \mathrm{~m}$.

LITHOLOGY: In the southern part of the Maungaharuru Range, south of Ahuateatua Trig and extending into Te

Fig. 4 Photographs of parts of Titiokura Formation at various localities along the western face of the Te Waka Range, southwest of Te Waka Trig. A, Titiokura Formation unconformably over Mokonui Formation, showing marked relief on the contact. The dark grey limestone on the left side of the photo view is c. $15 \mathrm{~m}$ thick, thins to $1 \mathrm{~m}$ over the Mokonui Formation high in the centre, and then thickens to the right to $>50 \mathrm{~m}$ thick. The overlying grey limestone is part of the Te Waka Formation. Location: V20/242130, view looking southwest. B, Titiokura Formation limestone gradationally overlain by concretionary sandstone facies of the Te Waka Formation. Location: V20/239128, looking north. C, Sandy limestone facies of the Titiokura Formation unconformably overlying concretionary, non-fossiliferous sandstone facies of the Mokonui Formation at Hells Hole, Te Waka Range. The limestone sheet is c. 50 m thick. Location: V20/235127, looking south. D, Contact between Titiokura Formation and Mokonui Formation. The $0.5 \mathrm{~m}$ thick bed above the contact comprises a conglomerate consisting of Tertiary sandstone and mudstone clasts. Relief on the contact is up to $0.3 \mathrm{~m}$. Location: V20/239128. E, Approximately $20 \mathrm{~m}$ thick outcrop of Titiokura Formation in foreground, above buff-coloured Mokonui Formation. Arrows denote surfaces defining broad "packages" within an otherwise single limestone sheet. Location: V20/241129, looking southwest. 


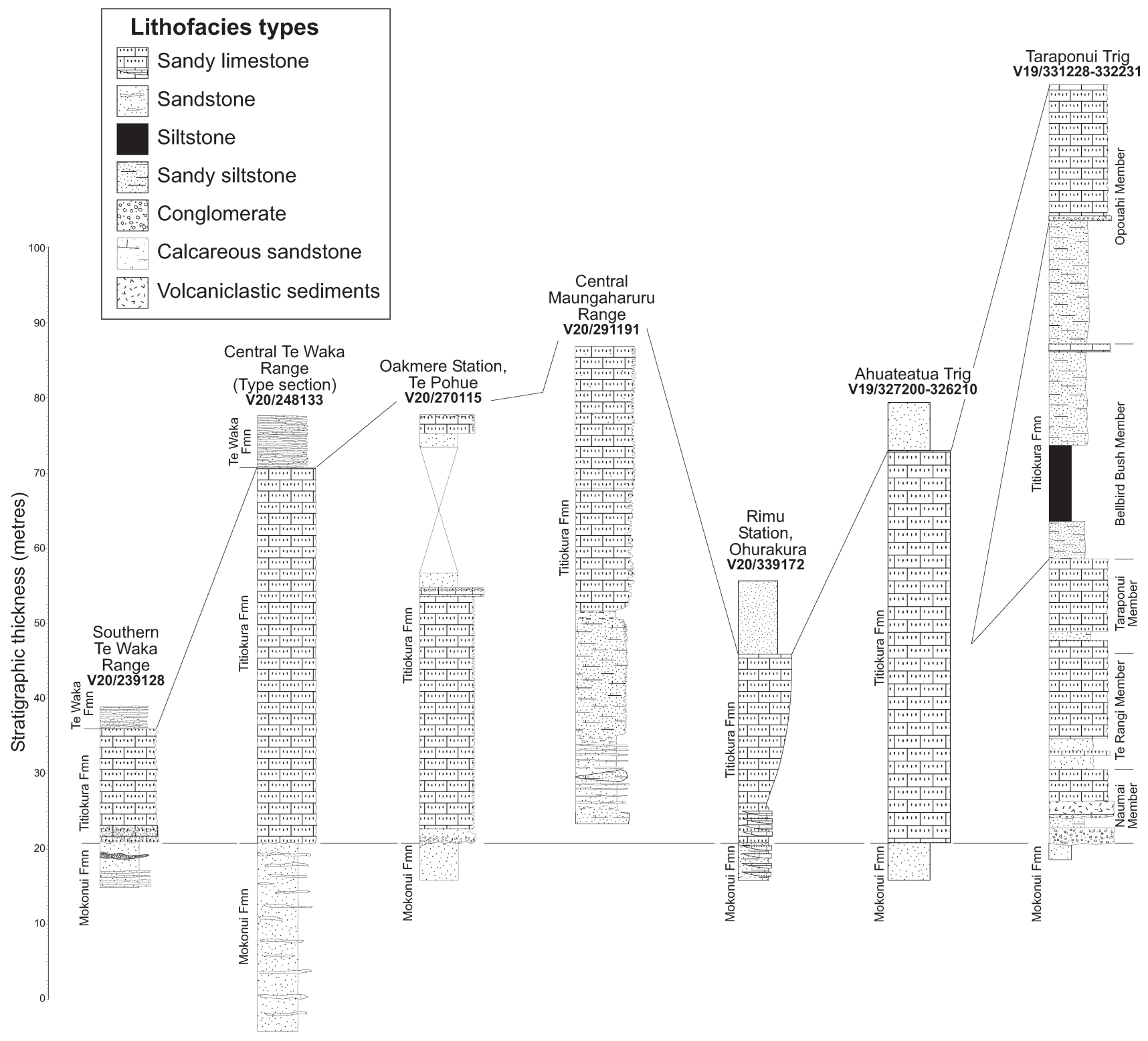

Fig. 5 Stratigraphic columns of the Titiokura Formation at localities within the Te Waka Range and southern part of the Maungaharuru Range. Note the differentiation from a principal limestone unit into more diversified lithologies at Taraponui Trig.

Waka Range, the Titiokura Formation consists chiefly of limestone that unconformably overlies sandstone facies of the Mokonui Formation (Fig. 2, 4, 5). The limestone comprises alternating coarsening-upward skeletal grainstone and mixed carbonate-siliciclastic packstone in tabular sets up to $30 \mathrm{~cm}$ thick. Cementation is more pronounced in the skeletal beds compared with siliciclastic beds (Caron 2002). Lower parts of the limestone are dominated by bivalve fragments and barnacle plates, passing up into bryozoan-rich facies (Caron 2002).

North of Ahuateatua Trig, the lithology of the Titiokura Formation becomes more diversified, with multiple limestone beds separated by silty sandstone and siltstone (Fig. 3, 5, 6, 7). Limestone units consist primarily of barnacle-bryozoan packstone to grainstone beds. Basal parts of the limestone beds consist largely of barnacle plates, and branching and encrusting bryozoans, with an increase in bryozoan content up-section. These beds are separated by fossiliferous sandstone and siltstone units that become thicker to the northeast. Also, with increasing distance to the north, particularly in the vicinity of Naumai and Te Rangi Stations (Fig. 2), the limestone units pass into cross-bedded fossiliferous sandstone (Graafhuis 2001).

PALEONTOLOGY AND AGE: The limestone sheet in the southern extent of the Titiokura Formation is composed of barnacle plates, fragmented bryozoans (robust-branching and encrusting types), and bivalve and echinoderm fragments. Macrofossils include Talochlamys gemmulata, Ostrea chilensis, Neothyris aff. obtusa (locally forming brachiopod beds), Amalda (Baryspira) mucronata, and rare Atrina pectinata zelandica. At Pohokura Saddle, the basal conglomerate contains rare Penion sp., Alcithoe sp., solitary corals, and shark teeth.

The occurrence of large Phialopecten marwicki and rare Mesopeplum crawfordi in the uppermost parts of Titiokura Formation in the Te Waka Range suggest a Waipipian age for 
Fig. 6 Stratigraphic columns of the Titiokura Formation in the Maungaharuru Range from Taraponui Trig north to Te Rangi Station, showing the differentiation into lithostratigraphic members.

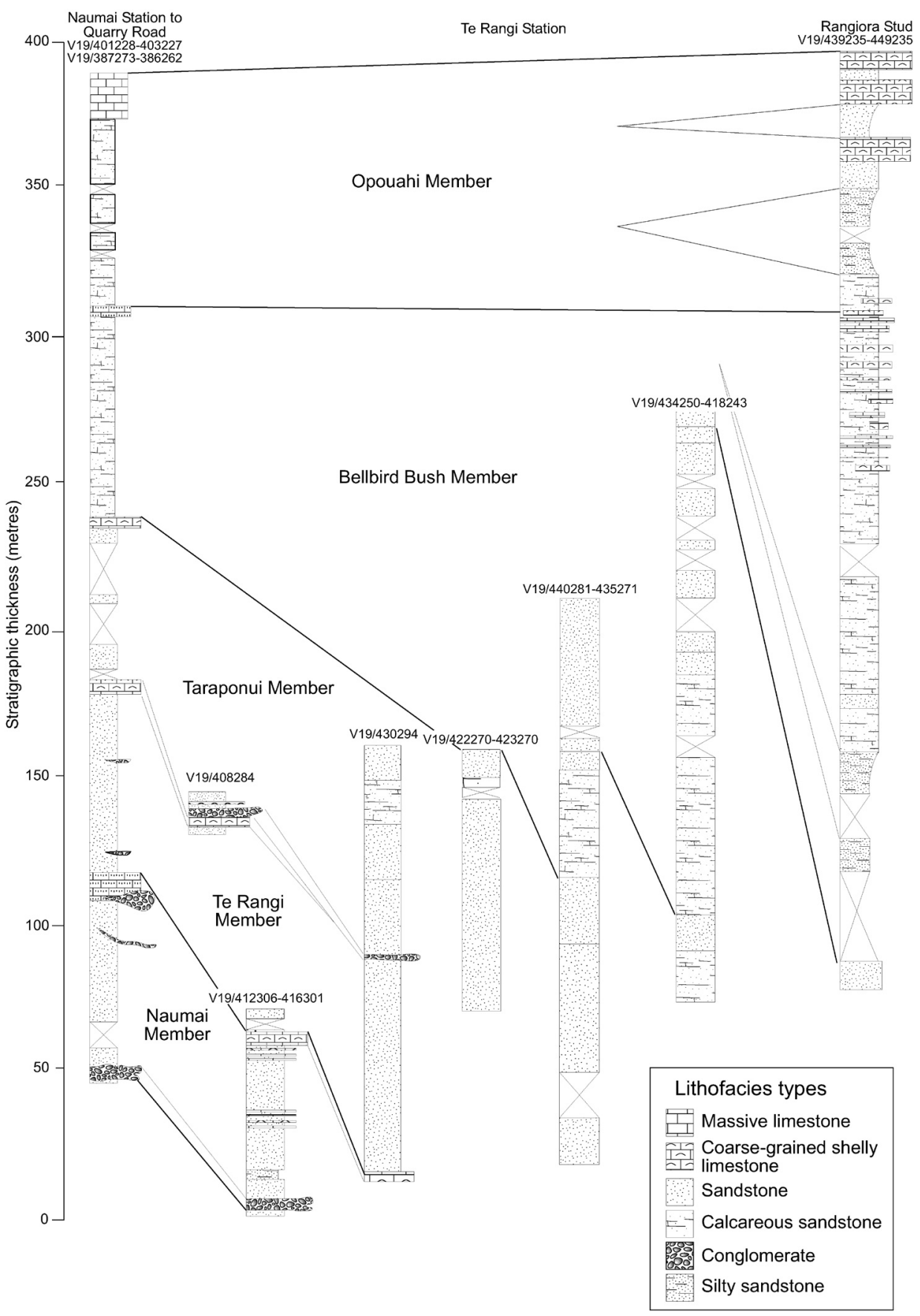

the beds (Beu 1995; Bland 2001). In the northern parts of the Maungaharuru Range, shellbed correlatives of the limestone units at Taraponui Trig (Fig. 5, 6) contain Crassostrea ingens and Opoitian forms of Phialopecten marwicki, suggesting an Opoitian age for this part of the formation. The underlying Mokonui Formation has been reported by Cutten (1994) to be of late Kapitian to early Opoitian age. The uppermost limestone unit (Opouahi Member) in Titiokura Formation corresponds to the beds reported by Beu (1995) to contain rare Mesopeplum crawfordi, suggesting an Opoitian or earliest Waipipian age.

The early Pliocene ages inferred from the relatively sparse age-diagnostic macrofossils identified by prior workers and ourselves, together with the thickness distribution of the formation and its members, suggest that the strata onlap to the south and offlap to the north and east.

In the following sections we establish five new members within Titiokura Formation. These include Naumai, Te Rangi, Taraponui, Bellbird Bush, and Opouahi Members (Fig. 6).

\section{Naumai Member (new)}

NAME AND DEFINITION: Naumai Member is named after Naumai Station at the crest of the Maungaharuru Range on Pohokura Road (Fig. 2), and is the lowest member in the Titiokura Formation. The member comprises a stratigraphic succession of conglomerate, calcareous sandstone or limestone, silty sandstone, and sandy limestone. 

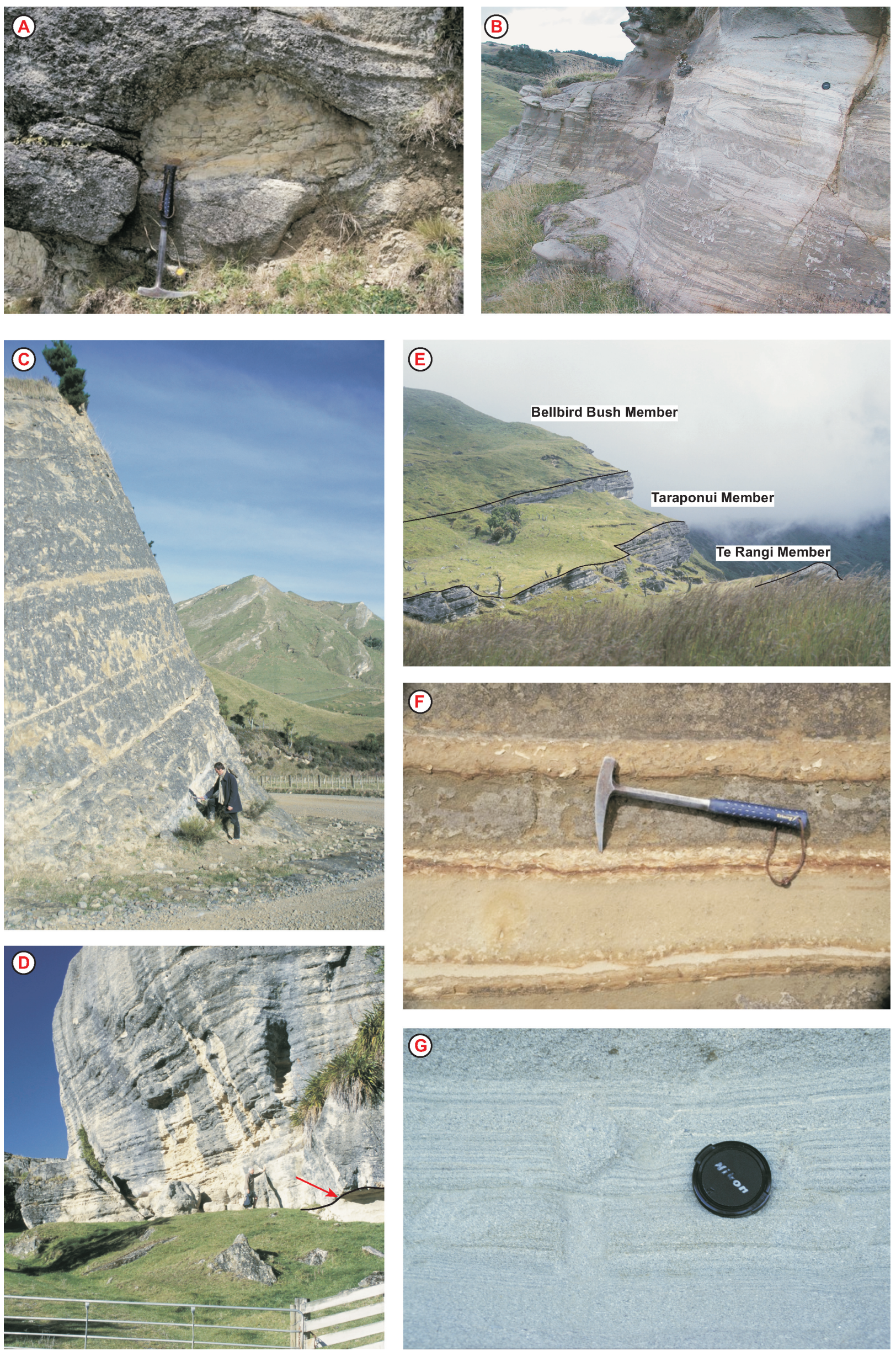
TYPE LOCALITY: The type section is designated on Pohokura Road at the crest of the range and within adjacent parts of Naumai Station (Fig. 8). The base of the member is very well exposed on Pohokura Road at V19/387273, being the roadcuts on the southern side of the intersection with Jeph Everett Road (Fig. 9B). The majority of the stratigraphic extent of the member is exposed in natural outcrops in the paddock on the northern side of Pohokura Road at this intersection, the top of the section being located at V19/ 386265. Reference sections have been drawn for Taraponui Trig (V19/331228) and on Te Rangi Station (V19/412306416301) (Fig. 6) (Graafhuis 2001).

DISTRIBUTION AND BOUNDARIES: Naumai Member has been mapped (1:50 000 scale) from the section below Ahuateatua Trig along the western face of the Maungaharuru Range to Te Rangi Station (Graafhuis 2001; Bland in prep.) (Fig. 2). The member also crops out east of the range crest in the sides of incised stream valleys, the broadest extent being at the end of Heayes Access Road on Te Rangi Station.

The base of Naumai Member, as identified north of Ahuateatua Trig, coincides with the base of the Titiokura Formation. Throughout the map area (Fig. 2), the lower contact is an erosional unconformity, possibly angular, most of the apparent discordance being due to channelisation and large scale cross-bedding, rather than to tectonic tilting. This contact varies from being sharp and planar to having a local relief up to $6 \mathrm{~m}$ over $10 \mathrm{~m}$ length of outcrop (Fig. 6, 8) Northwards from Te Rangi Station, which corresponds to a direction into the depocentre, the lower contact appears to become conformable. The upper contact of Naumai Member is considered to be a disconformity and is a sharp planar surface with minor local relief on it.

THICKNESS: At Taraponui Trig, Naumai Member is $15 \mathrm{~m}$ thick, which increases to c. $60 \mathrm{~m}$ in sections at Te Rangi Station. Most of the northeastward increase in thickness is due to thickening of sandstone facies comprising the middle to upper parts of the member. Basal conglomerate facies, by contrast, are thickest (up to $6 \mathrm{~m}$ ) in the southwest, reducing to c. $4 \mathrm{~m}$ in the northeast, although depending on the degree of channelisation, may not be present at any point along the outcrop extent. The limestone facies at the top of the member are also thickest in the southwest, being $9 \mathrm{~m}$ at Taraponui Trig.

LITHOLOGY: The basal beds of Naumai Member comprise various types of conglomerate and breccia. At the type section, basal channelised conglomerate comprises well-rounded and angular pebble to boulder size mudstone $(90 \%)$ and sandstone clasts $(10 \%)$ in a shelly sandstone matrix, which pass upwards into differentially cemented, bipolar cross-bedded, sandy limestone and calcareous sandstone, with rare mudstone clasts; this succession is repeated two or three times in the lower $6 \mathrm{~m}$ of the member at the type section (Fig. 7A, 9A,B). Greywacke pebbles are not prominent in the type section, but occur at localities above the contact to the south near Taraponui Trig, where pumice and charcoal fragments are locally conspicuous components of the conglomerate facies.

Sandstone beds comprise the bulk of Naumai Member in the type section and localities to the northeast (Fig. 6, 8). Lower parts are fine-grained sandstone to silty sandstone (Fig. 7F), with thin beds of sandy siltstone; upper parts are variably cemented, moderately calcareous and concretionary fine sandstone, with a few discontinuous and thin fine pebbly beds. The sandstone facies grade southward into limestone facies of the undifferentiated Titiokura Formation.

AGE: The Mokonui Formation underlying Naumai Member has an early Kapitean-Opoitian age in the Mohaka River section, and an early Opoitian age at Pohokura Road (Cutten 1994). Small size specimens of Phialopecten marwicki occur in the limestone facies of the Naumai Member, suggestive of an Opoitian age.

\section{Te Rangi Member (new)}

NAME AND DEFINITION: The name Te Rangi Member is derived from Te Rangi Station at the end of Heays Access Road (Fig. 2). This member has similar content and facies succession to Naumai Member, as described above.

TYPE LOCALITY: The type section is designated on Naumai Station at V19/387273-386262, being the succession immediately above the Naumai Member, and located immediately to the east and at higher elevation, involving natural outcrops in the same paddock (Fig. 6, 8). Reference sections have been logged for localities at Taraponui Trig (V19/331228), on Naumai Station (V19/392274, 407287) and on Te Rangi Station (V19/430297, 407287) (Graafhuis 2001).

DISTRIBUTION AND BOUNDARIES: Te Rangi Member immediately overlies Naumai Member and is distributed in a belt to the east of it, forming prominent dip-slopes on the flanks above deeply incised stream valleys (Fig. 2).

The lower boundary of the Te Rangi Member is sharp and erosional at Naumai Station, forming a disconformity. To the north at Te Rangi Station it is sharp, but possibly conformable. The upper boundary has similar character, locally showing relief of up to $60 \mathrm{~cm}$.

THICKNESS: The member is $20 \mathrm{~m}$ thick at Taraponui Trig (Fig. 5), thickening to c. $70 \mathrm{~m}$ in the vicinity of Naumai

Fig. 7 Photographs of parts of the constituent members of the Titiokura Formation in northern parts of the Maungaharuru Range. A, Conglomeratic limestone with large mudstone clast at the base of the Naumai Member (facies MX X $_{2}$, Naumai Station (V19/394277). B, Cross-bedded pumiceous sandstone (facies $S_{7}$ ) in upper parts of Te Rangi Member, Naumai Station (V19/392272). C, Calcareous sandstone (facies $\mathrm{MX}_{1}$ ) interbedded with thin siliciclastic siltstone beds, Bellbird Bush Member, Heays Access Road (V19/469253). D, Alternating grainstone and packstone beds (facies BC $_{1}$ ), Opouahi Member, Lake Opouahi (V19/408218). Note the sharp lower contact (arrowed) with underlying siltstone. E, View of Taraponui Member overlying Te Rangi Member in the western face of the Maungaharuru Range south of Naumai Station. Location: V19/370265, looking south. F, Alternating beds of siltstone and sandstone (facies $S_{6}$ ), Naumai Member, Naumai Station (V19/394273). G, Bioturbated, fine sandy packstone (facies MX $_{1}$ ) of Taraponui Member, Boundary Stream Reserve (V19/446270). 

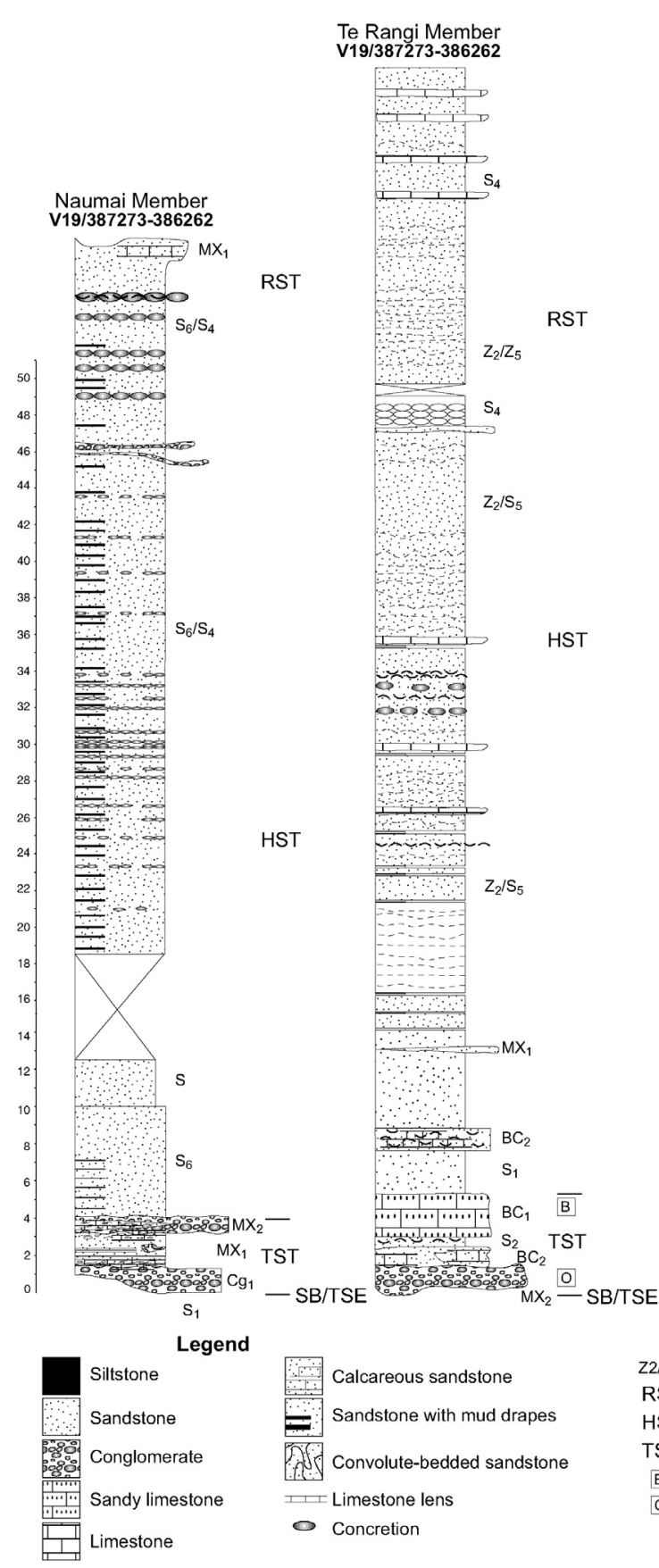
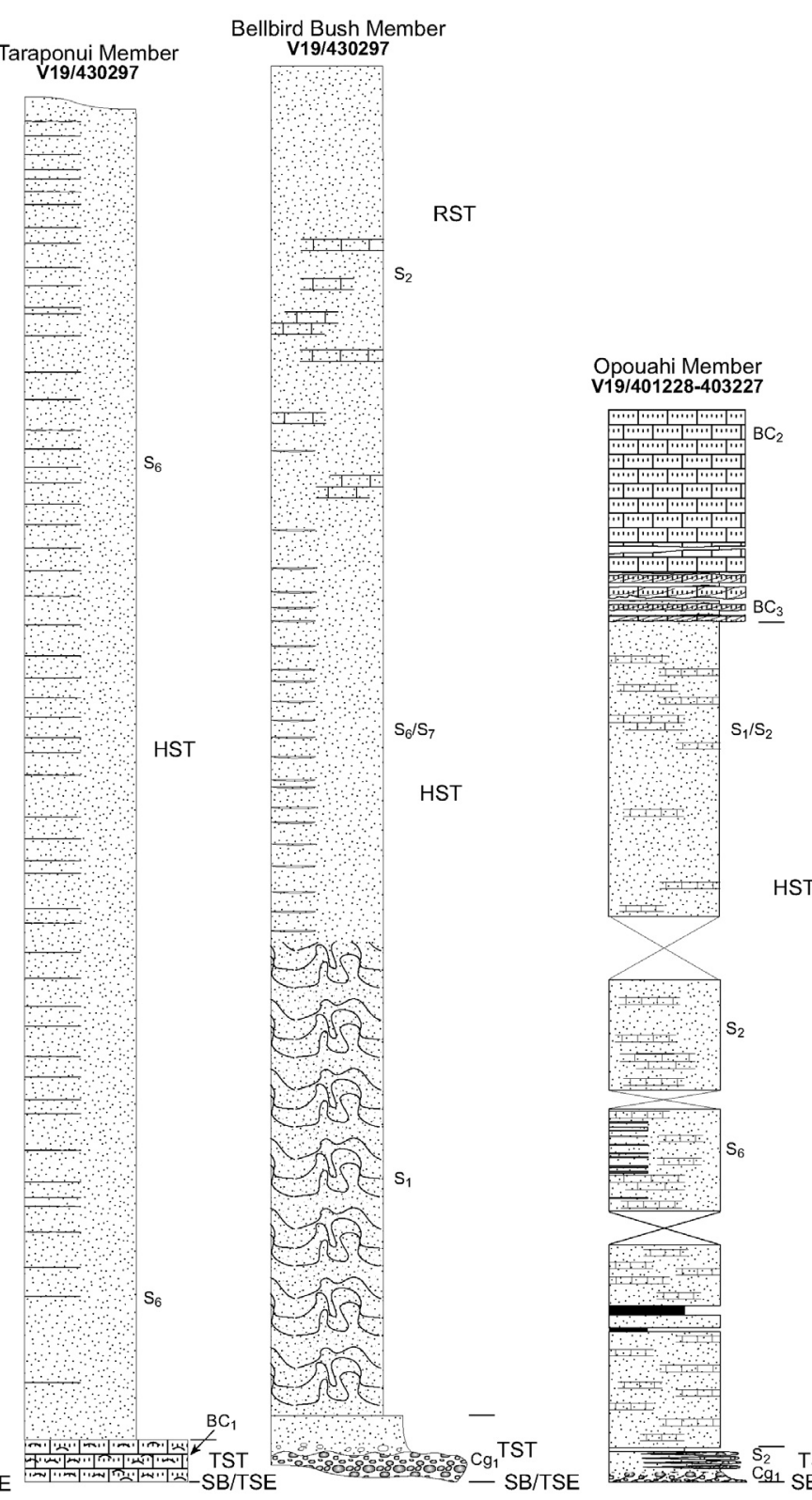

Z2/S5 Lithofacies type

RST Regressive systems tract

HST Highstand systems tract

TST Transgressive systems tract

B Backlap shellbed

0 Onlap shellbed

Fig. 8 Detailed stratigraphic logs for the type sections of the members in the Titiokura Formation in northern parts of the Maungaharuru Range, showing the vertical distribution of facies. Also shown are the positions of key sequence stratigraphic surfaces defining TST deposits and the stratigraphic extents of systems tracts.

Fig. 9 Examples of lithofacies in the Titiokura Formation. A, Concretionary sandstone (lithofacies $\mathrm{S}_{4}$ ) of the Mokonui Formation unconformably beneath basal conglomerate bed (lithofacies $\mathrm{Cg}_{1}$ ) of the Titiokura Formation. Location: cliff section below Taraponui Trig (V19/331236). B, Conglomerate lithofacies (lithofacies $\mathrm{Cg}_{1}$ ) at the base of the Naumai Member, Pohokura Road/Jeph Everett Road intersection, interbedded with concretionary sandstone (lithofacies $\left.\mathrm{S}_{4}\right)(\mathrm{V} 19 / 387273)$. C, Alternating packstone-grainstone beds (lithofacies $\mathrm{BC}_{1}$ ), passing up into more siliciclastic rich beds (lithofacies $\mathrm{BC}_{2}$ ), Opouahi Member, Pohokura Road (V19/403222). Note the prominent surfaces (arrowed) in this outcrop. D. Coarse-grained mixed bioclastic-siliciclastic lithofacies (lithofacies $\mathrm{MX}_{1}$ ) in fall blocks, southern Maungaharuru Range (V20/219191). E, Moderately dipping (c. 22 ${ }^{\circ}$ ), well-cemented, alternating packstone-grainstone beds (facies $\mathrm{BC}_{1}$ ), Ahuateatua Trig, central Maungaharuru Range (V19/327216). F, Skeletal limestone (lithofacies $\mathrm{BC}_{2}$ ) laterally passing into concretionary sandstone (facies $\mathrm{S}_{4}$ ), Te Waka Range south of Te Waka Trig (V20/235126). The Titiokura Formation unconformably overlies concretionary sandstone of the Mokonui Formation (also lithofacies $\mathrm{S}_{4}$ ). G, Skeletal-terrigenous limestone (lithofacies $\mathrm{BC}_{2}$ ) of the Titiokura Formation underlying concretionary sandstone (lithofacies $\mathrm{S}_{4}$ ) of the Te Waka Formation (V20/235126). 

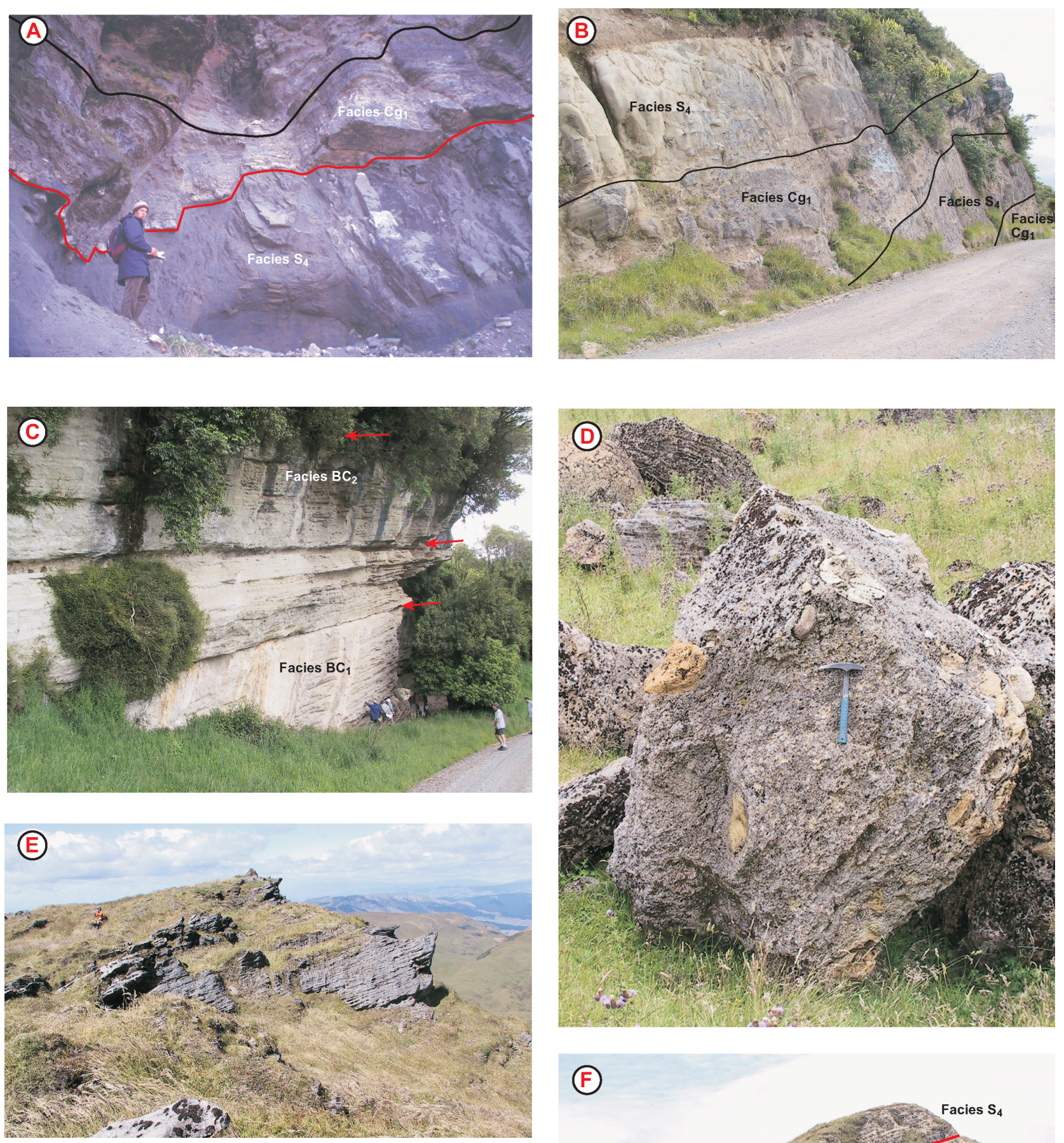

(F)
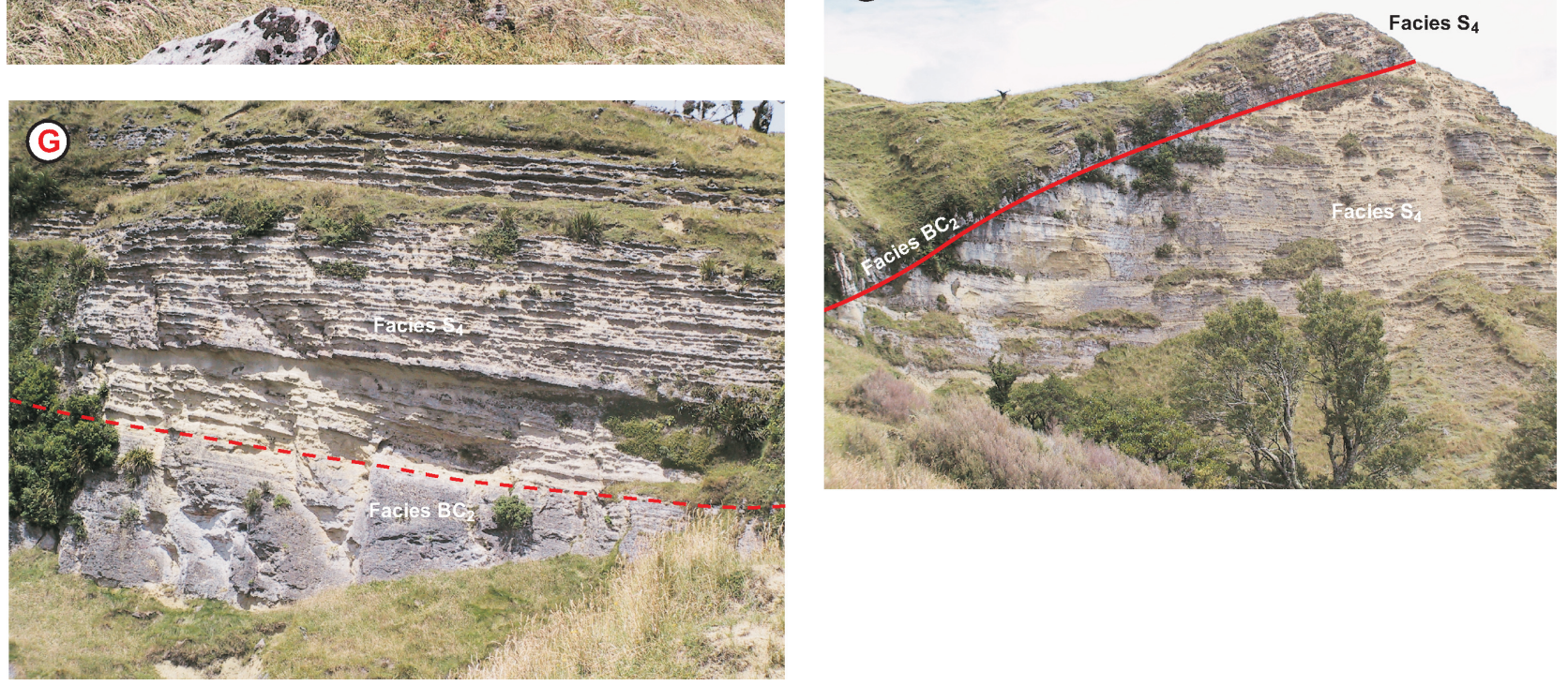
and Te Rangi Stations (Fig. 8). The northward increase in member thickness is due exclusively to substantial increases in the amount of siliciclastic sandstone within the bulk of the member.

LITHOLOGY: The base of Te Rangi Member at Naumai Station comprises a $0.5 \mathrm{~m}$ thick fossiliferous pebble to cobble greywacke conglomerate with disarticulated and fragmented bivalves, including Crassostrea ingens (Fig. 8, 9D). It is overlain by 1-2 m of cross-bedded, well-sorted calcareous sandstone, and then c. $1 \mathrm{~m}$ of moderately to well cemented, medium to coarse grained skeletal grainstone and packstone. This limestone is sharply overlain by $10 \mathrm{~m}$ of massive, noncemented, well-sorted fine sandstone, with occasional thin interbeds of cemented skeletal grainstone. The overlying $30 \mathrm{~m}$ of section is comprised of thin to medium bedded, non-cemented fine sandstone, sometimes with internal ripple bedding, convolute bedding, thin skeletal grainstone beds, and concretionary horizons. Bioturbation is obvious. The upper $30 \mathrm{~m}$ of the member is comprised of differentially cemented, medium to coarse grained, calcareous sandstone, displaying sets of megaripple to sand wave-scale trough and tabular cross-bedding, with convolute bedding and disrupted mud drapes (Fig. 7B). Sandstone beds and sets become more thickly bedded and cross-bedded upwards to the top of the member. Pumice is a conspicuous component of some crossbeds.

At Taraponui Trig the Te Rangi Member is $18 \mathrm{~m}$ thick, the lower $2 \mathrm{~m}$ comprising a grey calcareous fine sandstone, and the upper $16 \mathrm{~m}$ comprising cross-bedded fossiliferous grainstone with greywacke pebbles throughout, together with scattered, large sandstone rip-up clasts. In the vicinity of Rangiora and Te Rangi Station, the member comprises chiefly massive, bioturbated fine sandstone with mudstone drapes.

AGE: No age-diagnostic macrofossils have been identified in the member, which is inferred to be of Opoitian age, based on stratigraphic position.

\section{Taraponui Member (new)}

NAME AND DEFINITION: The name Taraponui Member is derived from Taraponui Trig on the crest of the Maungaharuru Range, where it is well exposed as a limestone unit. Northwards away from Taraponui Trig, the member is characterised by the occurrence of thick sandstone, with a limestone unit at its base (Fig. 6, 8).

TYPE LOCALITY: The type section is designated on Te Rangi Station at V19/430297, being the most accessible section where the whole of the member is exposed, including its lower contact (Fig. 8). Reference sections have been logged for localities at Taraponui Trig (V19/331228-332231), Naumai Station (V19/408284), Boundary Stream Walkway (V19/440281-435271), and Rangiora Stud (19/422270423270) (Graafhuis 2001).

DISTRIBUTION AND BOUNDARIES: Taraponui Member overlies Te Rangi Member and has a similar distribution to it (Fig. 2). The top of the member forms a prominent dip-slope that runs out to bluffs above deeply incised streams.

The lower boundary of the Taraponui Member is sharp and disconformable at localities between Taraponui Trig and
Te Rangi Station. The upper boundary is also a disconformity, showing relief of a few decimetres, but it is also rarely well exposed.

THICKNESS: The member is $10 \mathrm{~m}$ thick at Taraponui Trig, thickening to c. $75 \mathrm{~m}$ in the vicinity of Te Rangi and Rangiora Stations (Fig. 6, 8). As with the two underlying members, the northward increase in member thickness is due exclusively to substantial increases in the amount of siliciclastic sandstone within the bulk of the member.

LITHOLOGY: Taraponui Member comprises two main lithologies: a limestone or shellbed facies, which forms within the basal few metres of the member north of Taraponui Trig (Fig. 8), thickening up to comprise the bulk of the member $(10 \mathrm{~m})$ in the vicinity of Taraponui Trig (Fig. 5) and to the south of it; and sandstone facies, which form the bulk of the member in the vicinity of Naumai, Rangiora, and Te Rangi Stations. At Taraponui Trig the base of the member is a $0.5 \mathrm{~m}$ thick silty sandstone, overlain by moderately cemented, crossbedded, glauconitic grainstone (10 m), with mudstone rip-up clasts, rare pumice, and greywacke pebbles. Bioclasts are comprised of barnacle and echinoderm plates, and bryozoan and pecten fragments

At V19/408284 on Naumai Station, Taraponui Member has at its base a fossiliferous and cemented conglomerate, containing sandstone and mudstone clasts, and greywacke pebbles. This is overlain by $1-2 \mathrm{~m}$ of cross-bedded sandstone, and then a $0.5 \mathrm{~m}$ thick shellbed with rip-up clasts and flame structures at its base. At V19/386262 on the same property, the basal unit is a cross-bedded sandy limestone (grainstone) with mudstone and pumice clasts at its base. A similar single shellbed at the base of the member occurs on Te Rangi Station at V19/430297, but without the pumice and greywacke clasts. The lowermost beds appear to become amalgamated into one shellbed in a northeast direction, corresponding to a direction farther out into the basin.

Sandstone facies in Taraponui Member are 70-80 m thick, forming most of the member thickness (Fig. 8). Generally, lowermost parts are clean, fine sandstone with low-angle megaripple cross-beds, passing up into massive and ripple-bedded, bioturbated fine sandstone with mud drapes, reactivation surfaces, and differentially cemented concretionary horizons, and further upwards into amalgamated, well sorted, cross-bedded, fossiliferous fine sandstone (Fig. 7G).

AGE: No age-diagnostic macrofossils have been identified in Taraponui Member, which is inferred to be of Opoitian age, based on stratigraphic position.

\section{Bellbird Bush Member (new)}

NAME AND DEFINITION: Bellbird Bush Member is named after Bellbird Bush, a nature reserve near Naumai Station on the Maungaharuru Range (Fig. 2). The member is characterised by very thick accumulations of sandstone facies.

TYPE LOCALITY: The type section is designated on Te Rangi Station at V19/430297, where the member directly overlies the Taraponui Member, and the middle and lower parts of Bellbird Bush Member, including its lower contact, are exposed (Fig. 8). A reference section is located at V19/ 440281-435271 on Boundary Stream Walkway, where c. $110 \mathrm{~m}$ of the member is well exposed. Other good exposed 
sections occur at Taraponui Trig (V19/332231), on Quarry Road (V19/401228-4032270), on the steep-sided ridge on Rangiora Stud known to local residents as "Sharky Hill" (V19/439235-449235, 220 m of section exposed; V19434250-418243; V19/445255), and on Maori Gully Track (V19/405246) (Graafhuis 2001).

DISTRIBUTION AND BOUNDARIES: Bellbird Bush Member is extensively distributed in outcrop on the eastern flanks of the Maungaharuru Range (Fig. 2). It disconformably overlies Taraponui Member at Taraponui Trig and in the type section at Te Rangi Station, but appears to have a gradational contact in sections on Rangiora Stud to the east, which are located farther into the paleo-basin. The upper boundary is disconformable at Taraponui Trig, but conformable in other accessible sections located to the northeast.

THICKNESS: The Bellbird Bush Member is $25 \mathrm{~m}$ thick at Taraponui Trig, $70 \mathrm{~m}$ thick in the Waikoau River catchment, and $240 \mathrm{~m}$ thick to the northeast in the Waikari River catchment (Rangiora Stud) (Fig. 6). The dramatic increase in thickness into the paleo-basin is associated with the accumulation of sandstone facies.

LITHOLOGY: At the type section, a conglomerate containing subangular sandstone pebbles/clasts and numerous gastropods rests on a surface cut across Taraponui Member with $0.6 \mathrm{~m}$ of local relief (Fig. 8). This is overlain by fine clean sandstone with low-angle cross-beds. The lower $20 \mathrm{~m}$ of this sandstone section displays numerous zones of intricate convolutedly deformed beds, probably having a syn-sedimentary dewatering origin. This is overlain by $20 \mathrm{~m}$ of fine sandstone with megaripples, mud drapes (c. $2 \mathrm{~cm}$ thick), and internal cross-lamination. The mud drapes and sandstone beds are heavily bioturbated. This section passes into a $50 \mathrm{~m}$ thick section of cross-bedded fine sandstone with differentially cemented calcareous sandstone horizons.

The reference section on Boundary Stream Walkway is characteristic of other sections on Rangiora Stud. It appears to show a conformable base without a lower conglomerate bed or shellbeds, and comprises sandstone facies throughout. From bottom to top, the sandstone is parallel-laminated to cross-bedded (lower $25 \mathrm{~m}$ ), heavily bioturbated and crossbedded sandstone with mud drapes and concretionary horizons (middle $40 \mathrm{~m}$ ), and massive to parallel-laminated sandstone, with rare mudstone stringers and concretionary horizons (upper $45 \mathrm{~m}$ ) (Fig. 7C). In general, the upper third of the thickness of the member has common cemented horizons, reflecting a cleaner sandstone and higher carbonate content originating from finely comminuted shell hash. At Taraponui Trig, the Bellbird Bush Member comprises $23 \mathrm{~m}$ of thinbedded, fossiliferous sandy siltstone. This member may include part of the underlying limestone, included above in the Taraponui Member, as the position of the lower boundary is uncertain.

AGE: No age-diagnostic macrofossils have been identified in Bellbird Bush Member, which is inferred to be of Opoitian age, based on stratigraphic position.

\section{Opouahi Member (new)}

NAME AND DEFINITION: Opouahi Member is named after Lake Opouahi on the eastern flank of the Maungaharuru Range
(Fig. 2, 7D). The member is characterised by diversified lithologies, including silty sandstone, sandstone, and limestone, possibly forming cyclothems.

TYPE LOCALITY: The type section is designated on Quarry Road at V19/401228-403227 (Fig. 8). In this section, the base of the member is well exposed above $14 \mathrm{~m}$ of the upper part of Bellbird Bush Member. A reference section is located at V19/439235-449235 north of Matahorua Road, where it forms the topographically highest beds of "Sharky Hill".

DISTRIBUTION AND BOUNDARIES: Opouahi Member is distributed on the eastern flank of Maungaharuru Range, south and east of Bellbird Bush Member, where it forms the uppermost member of the Titiokura Formation (Fig. 2). East and south of the outcrop area of Opouahi Member, the elevation of the surface drops rapidly into the catchments of the Waikoau, Matahorua, and Waikari Streams. The member has a sharp disconformable base at the type section. At the reference section, the base is conformable with a transition from clean cross-bedded sandstone to silty sandstone. The upper contact of Opouahi Member has not been observed. The overlying unit is a massive fossiliferous siltstone (Rangiora Formation), and the contact is probably gradational.

THICKNESS: The Opouahi Member is $45 \mathrm{~m}$ thick at the type section where it has an eroded top. At the reference section it is $75 \mathrm{~m}$ thick, also with an eroded top.

LITHOLOGY: At the type section the base of the member comprises two beds of trough cross-bedded limestone (grainstone) $0.5 \mathrm{~m}$ thick, separated by laminated siltstone containing ripples (Fig. 8). The limestone beds contain c. 5\% greywacke granules, and sandstone and mudstone rip-up clasts. They are overlain by $1 \mathrm{~m}$ of cross-bedded fossiliferous sandstone, which passes upward into $43 \mathrm{~m}$ of weathered calcareous sandstone with abundant concretionary horizons. This sandstone is sharply overlain, probably disconformably, by $12 \mathrm{~m}$ of cross-bedded fossiliferous limestone containing greywacke granules (Fig. 9C). At the reference section there are two upward-coarsening cyclothems, in which $20 \mathrm{~m}$ of massive, bioturbated silty sandstone passes gradationally upward into bipolar cross-bedded, fossiliferous, concretionary sandstone containing greywacke granules. At Taraponui Trig there are also two sedimentary cycles represented in Opouahi Member. The lower one comprises a 1-2 m thick basal crossbedded shelly limestone lens with a disconformable base that grades sharply into a thin-bedded fossiliferous sandy siltstone. The upper one comprises a $9 \mathrm{~m}$ thick cross-bedded fossiliferous limestone with greywacke granules. It has a disconformable base.

AGE: The Opouahi Member may be of Opoitian or Waipipian age, based on the occurrence of Mesopeplum crawfordi within limestone facies (Beu 1995).

\section{LITHOFACIES AND DEPOSITIONAL PALEOENVIRONMENTS}

A first-order lithofacies analysis has been undertaken of the Titiokura Formation to help interpret the depositional setting and paleoenvironments in which the formation and its constituent members accumulated. Lithology and sedimentary 
structures are the two facies parameters emphasised in the descriptions; information about the paleoecology of the faunal components is difficult to assemble and interpret due to the fragmental nature of the macrofossils, and the degree of their sedimentary transportation and dispersal. The diagnostic characteristics of each facies are summarised in Table 1, the descriptive details not being repeated in the text. The vertical stratigraphic distribution of the various

Table 1 Lithofacies and inferred depositional paleoenvironments, Titiokura Formation.

\begin{tabular}{|c|c|c|c|c|}
\hline Code & Description & \multicolumn{2}{|c|}{$\begin{array}{l}\text { Relative } \\
\text { abundance }\end{array}$} & $\begin{array}{l}\text { Depositional } \\
\text { environment }\end{array}$ \\
\hline & BIOCLASTIC LITHOFACIES & South & North & \\
\hline $\mathrm{BC}_{1}$ & $\begin{array}{l}\text { ALTERNATING PACKSTONE/GRAINSTONE SHEETS; Moderately to well-cemented } \\
\text { medium to coarse-grained stacked skeletal grainstone/packstone sheets } 0.1-0.3 \mathrm{~m} \text { thick. } \\
\text { Skeletal grains of barnacle, bryozoan, and epifaunal bivalve material dominate the } \\
\text { composition of the facies. }\end{array}$ & $\mathbf{C}$ & $\mathrm{S} / \mathrm{C}$ & Inner to middle shelf \\
\hline $\mathrm{BC}_{2}$ & $\begin{array}{l}\text { ALTERNATING MIXED SKELETAL-TERRIGENOUS SHEETS; Slightly to well- } \\
\text { cemented alternating skeletal grainstone and mixed carbonate-siliciclastic packstone sheets } \\
\text { to } 0.3 \mathrm{~m} \text { thick. Skeletal grainstone beds are generally better cemented than layers with a } \\
\text { higher terrigenous component. }\end{array}$ & C & $\mathbf{S} / \mathbf{C}$ & Middle shelf \\
\hline $\mathrm{BC}_{3}$ & $\begin{array}{l}\text { PEBBLY LIMESTONE; Moderately to well-cemented medium to coarse-grained bioclastic- } \\
\text { dominated beds with common pebble to cobble-sized clasts of siliciclastic sandstone and } \\
\text { mudstone and Torlesse greywacke comprising less than } 50 \% \text { of the volume of the facies. }\end{array}$ & $\mathbf{S}$ & $\mathbf{R} / \mathbf{S}$ & $\begin{array}{l}\text { Inner shelf adjacent to siliciclastic } \\
\text { sediment input }\end{array}$ \\
\hline
\end{tabular}

\section{SILICICLASTIC LITHOFACIES}

$\mathbf{C g}_{1}$ CONGLOMERATE; Moderately to poorly-sorted non to moderately-fossiliferous conglomerate. Clasts are sub-angular to well-rounded and comprise a mixture of granule to boulder sizes, pebble to cobble-sized clasts predominate. Clasts are dominated by Tertiary sandstone and mudstone lithologies, with rare to common scattered basement material, and locally important pumice and carbonised logs. The matrix of this facies is siliciclastic sand, with rare to abundant shellhash in lenses through the unit.

BARREN SANDSTONE; Massive to cross-bedded, non-cemented very well-sorted non to slightly-fossiliferous fine to medium-grained sandstone. Foresets are of medium to large-scale, bedding is dominated by tabular and planar bedforms.

S $_{2} \quad$ CALCAREOUS SANDSTONE; Massive to cross-bedded, non-cemented very well-sorted moderately calcareous fine to medium-grained sandstone. Foresets are of medium to largescale, bedding is dominated by tabular and planar bedforms.

THIN-BEDDED SANDSTONE; Well-sorted, non-cemented fine-grained sandstone to sandy siltstone.

$\mathbf{S}_{4}$

CONCRETIONARY SANDSTONE; Non to well-cemented fine-grained slightly to moderately-calcareous sandstone with prominent concretions and cemented horizons. Non to slightly-fossiliferous and massive to thin-bedded.

$\mathrm{S}_{5}$

SANDSTONE WITH RIP-UP CLASTS; Non to well-cemented, fine-grained sandstone to sandy siltstone with common concretionary horizons and prominent sandstone and mudstone rip-up clasts. Occasional channelised structures occur. Rip-up clasts are composed of sandstone and mudstone lithologies.

S $\quad$ SANDSTONE WITH MUDSTONE STRINGERS; Non to well-cemented, fine-grained sandstone to sandy siltstone with common mudstone stringers up to $0.1 \mathrm{~m}$ thick that may extend laterally for many metres.

RIPPLE-BEDDED SANDSTONE; Non to slightly fossiliferous fine to medium-grained sandstone with ripple-bedded units, flaser bedding, cross-stratification, and common siltstone interbeds. Occasional channelised interbeds and calcareous lenses and horizons are present as are sandstone and siltstone rip-up clasts of pebble to cobble-size.

$\mathbf{Z}_{1} \quad$ MASSIVE SILTSTONE; Non-fossiliferous, massive to laminated siltstone, with rare, lowangle cross-bedding in sandstone interbeds.

$\mathbf{Z}_{2} \quad$ RIPPLE-BEDDED SILTSTONE; Non fossiliferous massive siltstone to fine sandstone with ripple bedding and mud drapes; disrupted mud clasts.

\section{MIXED BIOCLASTIC-SILICICLASTIC LITHOFACIES}

MX $\mathbf{1}_{1}$ MIXED TERRIGENOUS-SKELETAL SANDSTONE; Non to slightly-cemented mediumgrained mixed siliciclastic-carbonate sandstone, commonly cross-bedded with common mudstone lenses and stringers to 0.3 m thick.

$\mathbf{M X}_{2}$ FOSSILIFEROUS CONGLOMERATE; Pebble to cobble-dominated conglomerate with common valves of robust epifaunal and infaunal bivalves set in a matrix of mixed siliciclastic and bioclastic sediments. Crassostrea ingens is common, with scattered fragments of Phialopecten marwicki and some flabellid corals.

Ab C Inner shelf

Ab $\quad \mathbf{S}$ Inner shelf

Ab S Inner to middle shelf

Ab C Inner to middle shelf

Ab $\quad \mathbf{S}$ Inner to middle shelf

Ab S Innermost shelf

Ab $\quad \mathbf{S} \quad$ Middle to outer shelf

Ab $\quad \mathbf{S} \quad$ Middle to outer shelf

Ab S Shoreface to inner shelf, submarine channels

Ab $\quad \mathbf{S} \quad$ Inner to middle shelf

R $\quad$ S Inner shelf adjacent to siliciclastic sediment input

Abbreviations for relative abundance: $\mathrm{Ab}$, absent; $\mathrm{R}$, rare; $\mathrm{S}$, some; $\mathrm{C}$, common. South refers to locations south of Taraponui Trig; North refers to locations north of Taraponui Trig. 


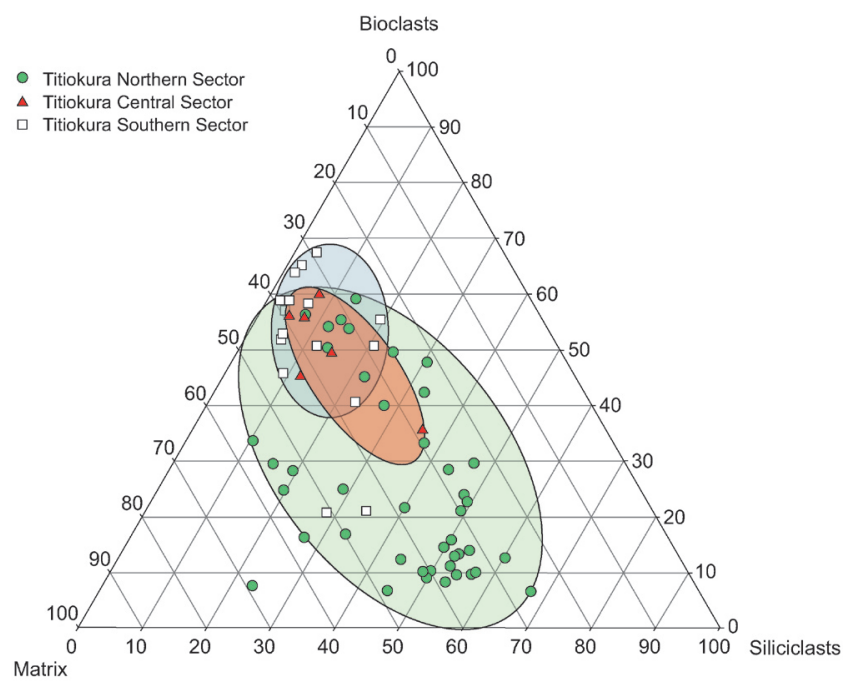

Fig. 10 Ternary plot of siliciclasts, bioclasts, and matrix/cement content of the Titiokura Formation derived from modal analysis of thin sections, separated into samples derived from southern, central, and northern parts of the Te Waka and Maungaharuru Ranges. Note the variability present in samples from the northern sector, reflecting the higher proportion of siliciclastic sediment, and the general trend from bioclastic-dominated to more mixed lithologies from south to north (cf. Fig. 3).

lithofacies, particularly within the lower three members, is shown in Fig. 5, 6, and 8. The lithofacies have been grouped into three associations, based on the proportion of siliciclastic and bioclastic components. Bioclastic lithofacies dominate southern areas of the Titiokura Formation, while siliciclastic lithofacies dominate in northern areas where the formation is mapped as five members. In the following text we outline some petrographic information about the sediments from thin-section derived point-count data of Titiokura Formation (Fig. 10), and interpret the depositional paleoenvironments from the field-based lithofacies descriptions.

\section{Bioclastic lithofacies}

In the southern parts of Titiokura Formation where limestone lithofacies predominate (Fig. 5), limestone beds are skeletal grainstones and packstones, with fragmented and abraded barnacle plates and bryozoan branches, as well as bivalve shells. Microborings are common, together with intraskeletal and detrital glauconite, supportive of prolonged seafloor residence for the deposits in this area. The matrix in skeletal packstones consists of a mixture of detrital carbonate mud, argillaceous material, and crypto/microcrystalline calcite cement. Skeletal grainstones are often impure, and their matrix-free biomoulds and interparticle pore space are cemented by equant calcite spar, typically exhibiting a drusy fabric.

Bioclastic lithofacies accumulated on a carbonatedominated shelf subjected to strong tidal currents at inner-middle shelf water depths (Kamp et al. 1988). The presence of dispersed greywacke clasts implies an emergent basement hinterland and substrate, probably in the southwest, to which bryozoans, bivalves, and brachiopods could attach. These lithofacies are inferred to have accumulated in water depths of $20-50 \mathrm{~m}$. The composition and discontinuous nature of individual sheets of lithofacies $\mathrm{BC}_{3}$ indicate a wave-dominated environment on an open shelf. The skeletal grainstone beds represent storm-emplaced sheets mobilised from carbonate factories and dispersed across a shelf. Lithofacies $\mathrm{BC}_{1}$ is thought to also represent sedimentation in a current-swept environment with individual skeletal grainstone and packstone sheets being products of sediment remobilisation off carbonate factories during storm events. The occurrence of burrows extending from overlying into underlying sheets, and sharp bases to beds in lithofacies $\mathrm{BC}_{1}$ and $\mathrm{BC}_{2}$, indicate that deposition of the sheets occurred as discrete sedimentation events.

\section{Siliciclastic lithofacies}

In the central and northern sectors, siliciclastic lithofacies become more common (Fig. 8, 10), comprising mixed skeletal-terrigenous packstones to wackestones and siliciclastic sandstone and siltstone. Skeletal grainstones are rare. The bioclastic component is dominated by strongly fragmented and abraded barnacle fragments and minor contributions from bivalves and bryozoans, and also benthic foraminifera and echinoderms. The observable siliciclastic component is made up of quartz, feldspar, and rock fragments, with occasional flakes of mica. Reduced average grain sizes result in an overall irresolvable matrix, which is most likely a mixture of detrital carbonate, argillaceous material, and cryptocrystalline calcite cement.

Deposition occurred on a shelf environment that at times was satiated with siliciclastic sediments, chiefly sandstone. The deposition of sandstone lithofacies (lithofacies $\mathrm{S}_{1}-\mathrm{S}_{7}$ ) took place on an inner-mid-shelf environment, with the accumulation of siltstone at middle shelf depths. The accumulation of conglomerate lithofacies represents highenergy deposition of clasts in beach to fan-delta settings. The presence of Tertiary sandstone and mudstone clasts in lithofacies $\mathrm{Cg}_{1}, \mathrm{~S}_{5}$, and $\mathrm{Z}_{2}$ is suggestive of emergent areas of older basin fill in the hinterland. A tidal influence is inferred for the deposition of lithofacies $S_{7}$ based on the occurrence of flaser bedding, ripple-laminations, and bipolar crossstratification. The thickness of sandstone within the members of the Titiokura Formation implies that sand was able to be dispersed well out on to the shelf, possibly to mid-shelf water depths.

\section{SEQUENCE STRATIGRAPHY}

The Titiokura Formation accumulated during a period of known 41000 yr 6th order global sea-level oscillations of c. 75 m magnitude (Kamp et al. 2002, 2004; Vonk et al. 2002), as established from correlative strata in Wanganui Basin. We anticipate, therefore, the occurrence of 6th order cyclothems or sequences in Titiokura Formation. The constituent members of the Opoitian Titiokura Formation exhibit many of the characteristics of the siliciclastic-dominated sequences evident in the late Miocene and early Pliocene (Kapitean to early Opoitian) Matemateaonga Formation of Wanganui Basin (Vonk et al. 2002; Hendy \& Kamp 2004), and hence we suggest that they may also have a $41000 \mathrm{yr}$ periodicity, although specific age control is not available.

In the following text we outline the characteristics of the sequences, suggesting that Naumai, Te Rangi, Taraponui, and Bellbird Bush Members are individual sequences, and that there are at least two sequences in the Opouahi Member. These members become amalgamated south of Taraponui Trig 
and pass into the main limestone unit of Titiokura Formation (Fig. 3, 5). The next phase of our research will be to identify discrete sequences within this amalgamated limestone, using the sedimentological and diagenetic approaches and techniques developed by Caron \& Nelson (2003) for subdivision of the Opoitian Kairakau and Waipipian Awapapa Limestone units in the southeastern parts of Hawke's Bay Basin.

\section{Key surfaces}

The location of successive sequence boundaries is required to enable subdivision of a succession into sequences. On Naumai and Te Rangi Stations we can confidently identify sharp disconformable lower sequence boundaries for the base of each of Naumai, Te Rangi, Taraponui, and Bellbird Bush Members, as described above. The geomorphic expression of these boundaries is sufficiently well marked to enable these members or sequences to be mapped over considerable areas (Fig. 2). These sequence boundaries may initially have formed as subaerial erosion surfaces, but they are not associated with non-marine sediments nor paleosols; the surfaces have probably been modified by wave erosion during marine transgression and consequently they are ravinement surfaces, otherwise known as transgressive surfaces of erosion (TSEs) (e.g., Naish \& Kamp 1997; Kamp \& McIntyre 1998). Away from the type section, the base of Opouahi Member is a gradational boundary and is best described as a correlative conformity, having formed as a result of a sea-level lowering without subaerial exposure or impingement of the wave-base of erosion upon the contemporary seafloor.

The other key surface that can be identified within the Titiokura sequences is the downlap surface, which approximates the stratigraphic position of the maximum flooding surface (Naish \& Kamp 1997). This lies only up to a few metres above the sequence boundary, as described in the following text, and marks the progradation of facies belts in response to the development of relative highstand sea-level conditions, or the start of relative sea-level fall, the details of this timing depending upon the sediment flux and distance across the shelf-slope profile from the highstand shoreline. The usefulness of identifying the downlap surface is that it enables the transgressive systems tracts (TST) to be separated from the highstand (HST) and regressive systems tracts (RST). Other flooding surfaces besides the sequence boundary, or surfaces of regression, have not been identified in the Titiokura sequences.

\section{Systems tracts}

The lower four members of Titiokura Formation have clearly distinguishable thin TSTs that are comparable to the types of TSTs forming the lower parts of sequences in the Matemateaonga Formation in King Country Basin (Vonk et al. 2002). HSTs and RSTs form the majority of the thickness of the members and are dominated by sandstone facies. It is not possible to place a definitive boundary in these sequences between the HST and RST deposits.

The beds at the base of Naumai Member at Pohokura Saddle comprise several sets of channels infilled with large mudstone and sandstone clasts and a calcareous sandstone matrix (Fig. 7A, 9B). These channels reflect active marine erosion of underlying beds, and contemporary deposition, probably in a subtidal setting under rising sea-level conditions. The channelised conglomerate facies pass into c. $6 \mathrm{~m}$ of differentially cemented, clean calcareous sandstone, which we infer to be the upper part of the TST; overlying beds are uncemented, slightly silty sandstone with mud layers, reflecting quieter energy levels and accumulation in inner to mid-shelf conditions as HST deposits. The carbonate content of the sandstone facies increases upward, expressed in the development of concretionary horizons and cleaner sandstone, which we associate with higher wave energy in inner shelf to shoreface environments, more active progradation, and falling sea-level conditions consistent with classification as RST deposits.

The Te Rangi Member on Naumai Station shows a typical Wanganui-type TST (Naish \& Kamp 1997): a 1-2 m thick lower calcareous sandy conglomerate represents an onlap deposit akin to an onlap shellbed and is separated from a $2 \mathrm{~m}$ thick backlap shellbed composed of a sandy limestone by a $3 \mathrm{~m}$ thick fossiliferous sandstone. The downlap surface rests upon the top of the backlap shellbed. The HST comprises well-sorted, non-cemented fine sandstone, with convoluted deformation structures and thin mudstone layers, which passes up into a RST characterised by wavy and trough cross-bedded calcareous sandstone, with abundant convolute deformation structures, a few concretionary horizons, and differential cementation. The coarseness of the sand is due to the finely comminuted shell hash content. The paleobathymetry probably shallows from just above the downlap surface up to the sequence boundary, and the syn-sedimentary deformation structures, arising from rapid loading and catastrophic water escape, are an expression of the very rapid sediment accumulation rates associated with infilling of the paleobathymetric "hole" created by the eustatic sea-level rise during a transgression, combined with minimal TST thickness (e.g., Kamp \& Naish 1998). This sequence, as with the Naumai sequence, is highly asymmetric, with a thin TST and very thick HST and RST.

The sequence mapped as the Taraponui Member also has a thin TST. In one locality on Naumai Station (V19/408284) it has the same architecture as the Naumai sequence, with a $1 \mathrm{~m}$ thick conglomeratic onlap shellbed, a thin siliciclastic wedge, and a $0.5 \mathrm{~m}$ thick backlap shellbed. At the type section on Te Rangi Station and at another locality on Naumai Station (V19/386262), the TST comprises a single shellbed up to $3 \mathrm{~m}$ thick, which shows the characteristics of a compound shellbed (Naish \& Kamp 1997). The onlap and backlap components are collapsed together without an intervening nearshore siliciclastic wedge. The HST and RST components of the sequence are composed of bioturbated fine sandstone with disrupted mudstone drapes, grading into calcareous, cross-bedded fine sandstone with concretionary horizons, suggestive of gradually decreasing water depths within strongly progradational (regressive) inner shelf to shoreface deposits.

At the type section of the Bellbird Bush Member (V19/ 430297), the TST comprises a single shellbed and conglomerate (Fig. 8), which is probably a compound shellbed. The base of the sequence is infrequently exposed at other accessible sections. The HST/RST components of the sequence on Naumai and Te Rangi Stations are composed of sandstone with identical facies characteristics to the HST/RST of Taraponui sequence. However, at easternmost outcrop sections (e.g., Sharky Hill, V19/439235-449235) the lower half of the HST/RST is a massive sandy siltstone, which grades up into a massive sandstone, and then into a cross-bedded, calcareous sandstone with abundant cemented horizons. 


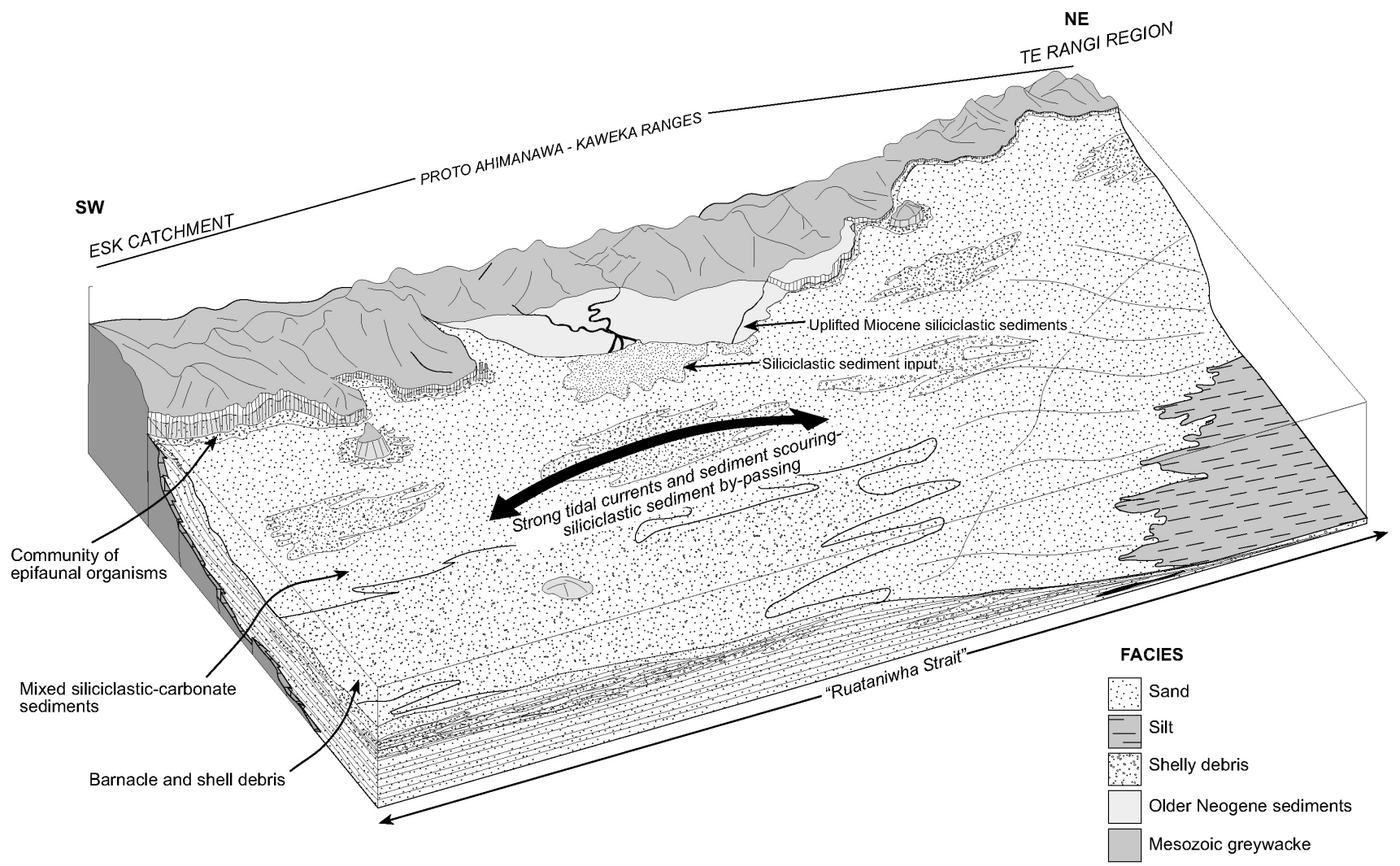

Fig. 11 Paleogeographic reconstruction of the inferred depositional setting for the Titiokura Formation in the early Pliocene.

The Opouahi Member is composed of two or more sequences, each inferred to be of $41000 \mathrm{yr}$ duration. At the type section on Quarry Road, the lower sequence has two thin shellbeds separated by a thin siltstone, and we interpret this package as the TST. This is overlain by $43 \mathrm{~m}$ of typical HST/RST sandstone. The overlying succession is an 11 $\mathrm{m}$ thick limestone (Fig. 7D) adjacent to Pohokura Road (Fig. 9C). In it there are three prominent stratigraphic breaks. We are uncertain about the sequence stratigraphic significance of these surfaces. The degree of limestone development in Opouahi Member in the vicinity of Pohokura Road is atypical in this part of the basin, and contrasts with the siliciclastic dominance of lower members of Titiokura Formation. Its occurrence at the top of the Titiokura Formation heralds a change in the basin development, and a dramatic decrease in the rate of siliciclastic sediment supply with the transition into the Rangiora Formation (Graafhuis 2001). On Sharky Hill, which lies farther to the east, the Opouahi Member contains two thin siliciclastic sequences that comprise lower sandy siltstone units (HST) that grade upward into cross-bedded calcareous sandstone units (RST). TSTs are cryptic as the sequence boundaries are probably correlative conformities.

\section{PALEOGEOGRAPHY}

The formation of the Mohaka River valley has removed the contemporary stratigraphic relationships between the Titiokura Formation and the basement now exposed in the ranges to the west. It is not clear, therefore, whether or not there was a western basin margin during sediment accumulation, and the extent to which basement was exposed, if at all, at that time. The onlap of Opoitian Pakaututu Formation and Omahaki Formation on to basement in the vicinity of Puketitiri, near the southern outcrop extent of the Titiokura Formation (Fig. 1), indicates that a rocky shoreline was present in the south during accumulation of Titiokura Formation. We infer therefore that the Titiokura Formation, as mapped in outcrop (Fig. 2), represents an oblique northeastsouthwest cross-section through a depositional system on a paleoshelf that was attached to a basement shoreline in the south, and downlapped into a basin depocentre to the northeast and east (Fig. 11).

The limestone-dominated parts of the Titiokura Formation developed seaward of a rocky shoreline, probably in inner shelf water depths. Strong tidal currents, coupled with adequate nutrient supply, promoted the growth of epifaunal organisms such as barnacles, bryozoans, pectinids, and oysters (Kamp et al. 1988). Carbonate factories were probably located around shoreline to inner shelf rocky (basement) substrates. Locally, greywacke pebbles can be important components of the limestone beds, as in Opau Stream near Patoka (Kingma 1958; Katz 1973), supporting the concept of a seascape with numerous rocky islands. The carbonate sediment was comminuted by wave and strong tidal action and dispersed on to the shelf where it accumulated. The rocky shorelines were not supplied with high siliciclastic sediment load. The origin of the siliciclastic sand and the direction of its transport on to the shelf have not been resolved in this study, but may have been sourced from the northwest to have avoided the rocky shoreline in the south. The paleobathymetry in northern parts of the study area was greater than that to the south, allowing for increased accommodation of the large volumes 
of siliciclastic sediment that accumulated as the constituent members of the Titiokura Formation (Fig. 11).

\section{DISCUSSION}

The Te Waka and Maungaharuru Ranges are very prominent landforms in western parts of Hawke's Bay, rising to over $1000 \mathrm{~m}$ above sea level. This paper presents for the first time a systematic stratigraphic description of the architecture of the early Pliocene sedimentary succession that underlies these ranges, and aspects of its sedimentology and sequence stratigraphy.

In the Te Waka Range and the southern part of the Maungaharuru Range, the Titiokura Formation comprises a single limestone sheet with calcareous sandstone parts. In the vicinity of Taraponui Trig and to the northeast, our 1:50 000 mapping (Bland 2001; Graafhuis 2001) (Fig. 2) shows that the limestone partitions into five members, which thicken markedly to the northeast, and concomitantly become dominated by siliciclastic sandstone (Fig. 3).

The Titiokura Formation is of early Pliocene age, based on macrofossil content, which is consistent with a Kapitean to early Opoitian age for the underlying Mokonui Formation (Cutten 1994). The occurrence of Phialopecten marwicki and Mesopeplum crawfordi within limestone facies of the Titiokura Formation suggests an Opoitian-Waipipian age for the formation (Austin Hendy pers. comm. 2003). All of the sediment accumulation could have occurred within 250000 $\mathrm{yr}$ if the six sequences we have identified accumulated during successive obliquity-controlled $41000 \mathrm{yr}$ sea-level oscillations, which are known to have been a major control on sedimentation at that time. If so, the Titiokura Formation could either be of early Opoitian age, which would emphasise a major reduction in siliciclastic sedimentation in the basin during the late Opoitian and Waipipian, or be of late Opoitian-Waipipian age, which would emphasise the amount of time missing in the unconformity between the Mokonui Formation and Titiokura Formation. Further efforts at dating the sediments will resolve these alternatives.

Given the age control available at present, and our lithostratigraphic correlations along the crest of the ranges, we suggest that the Titiokura Formation, and its correlatives to the south around Puketitiri, represent a shoreline-to-shelf linked depositional system. Carbonate production was focused around a rocky seascape as the system onlapped basement in the south, with dispersal and deposition of this carbonate debris on an inner shelf to the north, surprisingly devoid of siliciclastic sediment. The gradual differentiation into thick siliciclastic members farther to the northeast, which nevertheless maintained inner to mid-shelf paleo-environments, indicates that the rates of both subsidence and sediment flux increased rapidly in that direction, with active progradation and offlap of the depositional system into more axial parts of Hawke's Bay Basin. Future work will detail the internal sedimentological and diagenetic features that accompany the lithological changes within this oblique shoreline-to-shelf depositional system, which we have reconstructed over a length of $50 \mathrm{~km}$, a rare geological situation in Hawke's Bay Basin.

\section{ACKNOWLEDGMENTS}

We thank Department of Conservation staff at the Boundary Stream Reserve Mainland Island Headquarters, the Vellar family of Tutira, and the Wills family of Te Pohue for their generous provision of accommodation during parts of this investigation. Austin Hendy and Alan Beu are thanked for help with identification of macrofauna. Funding for this project came from the Marsden Fund (UOW801), Foundation for Research, Science and Technology (FRST) (UOWX0301), a FRST Top Achiever Doctoral scholarship (to Kyle Bland), and DAAD funds (to Arne Pallentin).

\section{REFERENCES}

Beu, A. G. 1995: Pliocene limestones and their scallops. Institute of Geological \& Nuclear Sciences Monograph 10. Lower Hutt, New Zealand, Institute of Geological \& Nuclear Sciences Ltd. 243 p.

Beu, A. G.; Grant-Taylor, T. L.; Hornibrook, N. de B. 1980: The Te Aute limestone facies, Poverty Bay to northern Wairarapa. New Zealand Geological Survey Miscellaneous Series Map 13. Scale 1:250 000. 2 sheets and map notes. Wellington, New Zealand, Department of Scientific and Industrial Research. 30 p.

Bland, K. J. 2001: Analysis of the Pliocene forearc basin succession, Esk River catchment, Hawke's Bay. Unpublished MSc thesis, lodged in the Library, The University of Waikato, Hamilton, New Zealand. 233 p.

Bland, K. J.; Nelson, C. S.; Kamp, P. J. J. 2003: Latest Miocene-Early Pleistocene onlap limestone beds in the western forearc basin, Hawke's Bay. Geological Society of New Zealand Miscellaneous Publication 116A: 21.

Caron, V. 2002: Petrogenesis of Pliocene limestones in southern Hawke's Bay, New Zealand: a contribution to unraveling the sequence stratigraphy and diagenetic pathways of coolwater carbonate facies. Unpublished $\mathrm{PhD}$ thesis, lodged in the Library, The University of Waikato, Hamilton, New Zealand. $445 \mathrm{p}$.

Caron, V.; Nelson, C. S. 2003: Developing concepts of highresolution diagenetic stratigraphy for Pliocene cool-water limestones in New Zealand, and their sequence stratigraphy. Carbonates and Evaporites 18: 63-85.

Caron, V.; Nelson, C. S.; Kamp, P. J. J. 2004: Contrasting carbonate depositional systems for Pliocene cool-water limestones cropping out in central Hawke's Bay, New Zealand. New Zealand Journal of Geology and Geophysics 47: 697-717 (this issue).

Cutten, H. N. C. 1994: Geology of the middle reaches of the Mohaka River. Institute of Geological \& Nuclear Sciences Geological Map 6. Scale 1:50 000. 1 sheet and 38 p. Lower Hutt, New Zealand, Institute of Geological \& Nuclear Sciences Ltd.

Erdman, C. F.; Kelsey, H. M. 1992: Pliocene and Pleistocene stratigraphy and tectonics, Ohara Depression and Wakarara Range, North Island, New Zealand. New Zealand Journal of Geology and Geophysics 35: 177-192.

Francis, D. A. 1991: Report on the geology of the Te Pohue area, western Hawke's Bay (PPL 38316) with emphasis on stratigraphy and structure. Unpublished open-file petroleum report PR 1750. New Zealand, Ministry of Commerce.

Graafhuis, R. B. 2001: Stratigraphy and sedimentology of Pliocene strata in the forearc basin (Waikoau and Waikari river catchments), northern Hawke's Bay. Unpublished MSc thesis, lodged in the Library, The University of Waikato, Hamilton, New Zealand. 218 p.

Grindley, G. W. 1960: Sheet 8-Taupo. Geological map of New Zealand 1:250 000. Wellington, New Zealand, Department of Scientific and Industrial Research.

Hendy, A. J. W.; Kamp, P. J. J. 2004: Late Miocene to early Pliocene biofacies of Wanganui and Taranaki Basins, New Zealand: applications to paleoenvironmental and sequence stratigraphic analysis. New Zealand Journal of Geology and Geophysics 47: 769-785 (this issue). 
Kamp, P. J. J. 1982: Landforms of Hawke's Bay and their origin a plate tectonic interpretation. In: Soons, J. M.; Selby, M. J. ed. Landforms of New Zealand. Auckland, Longmans. Pp. 233-254.

Kamp, P. J. J.; McIntyre, A. 1998: The stratigraphic architecture of Late Pliocene (2.8-2.4 Ma) asymmetrical shelf sequences, western Wanganui Basin, New Zealand. Sedimentary Geology 122: 53-67.

Kamp, P. J. J.; Naish, T. R. 1998: Forward modelling of the sequence stratigraphic architecture of shelf cyclothems: application to late Pliocene sequences, Wanganui Basin (New Zealand). Sedimentary Geology 116: 57-80.

Kamp, P. J. J.; Harmsen, F. J.; Nelson, C. S.; Boyle, S. F. 1988 Barnacle-dominated limestone with giant cross-beds in a non-tropical, tide-swept, Pliocene forearc seaway, Hawke's Bay, New Zealand. Sedimentary Geology 60: 173-195.

Kamp, P. J. J.; Vonk, A. J.; Bland, K. J.; Griffin, A. G.; Hayton, S.; Hendy, A. J. W.; McIntyre, A. P.; Nelson, C. S.; Naish, T. R. 2002: Megasequence architecture of TaranakiWanganui-King Country Basins and Neogene progradation of two continental margin wedges across western New Zealand. New Zealand Petroleum Conference Proceedings, 24-27 February 2002. Wellington, Ministry of Economic Development. Pp. 464-481.
Kamp, P. J. J.; Vonk, A. J.; Bland, K. J.; Hansen, R. J.; Hendy, A. J. W.; McIntyre, A. P.; Ngatai, M.; Cartwright, S. J.; Hayton, S.; Nelson, C. S. 2004: Neogene stratigraphic architecture and tectonic evolution of Wanganui, King Country, and eastern Taranaki Basins, New Zealand. New Zealand Journal of Geology and Geophysics 47: 625-644 (this issue).

Katz, H. R. 1973: Pliocene unconformity at Opau Stream, Hawke's Bay, New Zealand. New Zealand Journal of Geology and Geophysics 16: 917-925.

Kingma, J. T. 1957: The geology of the Kohurau fault block, central, Hawke's Bay. New Zealand Journal of Science and Technology B38: 342-353.

Kingma, J. T. 1958: The structural position of the Opau greywackes, Hawke's Bay. New Zealand Journal of Geology and Geophysics 1: 490-500.

Naish, T.; Kamp, P. J. J. 1997: Sequence stratigraphy of sixthorder (41 ka) Pliocene-Pleistocene cyclothems, Wanganui Basin, New Zealand: a case for the regressive systems tract. Geological Society of America Bulletin 109: 978-999.

Pettinga, J. R. 1982: Upper Cenozoic structural history, southern Hawke's Bay, New Zealand. New Zealand Journal of Geology and Geophysics 25: 149-191.

Vonk, A. J.; Kamp, P. J. J.; Hendy, A. J. W. 2002: Outcrop to subcrop correlations of late Miocene-Pliocene strata, eastern Taranaki Basin. New Zealand Petroleum Conference Proceedings, 24-27 February 2002. Wellington, Ministry of Economic Development. Pp. 234-255. 